\author{
Małgorzata Ostrówka, Ewa Golachowska \\ Instytut Slawistyki PAN \\ Warszawa
}

\title{
BOBRUJSZCZYZNA - OJCZYZNA FLORIANA \\ CZARNYSZEWICZA WCZORAJ I DZIŚ (RAPORT Z BADAŃ TERENOWYCH)*
}

\section{Cel wyjazdu}

Badania terenowe w Bobrujsku i okolicach są częścią podjętych w ostatnim czasie badań, skupiających się na dwóch głównych zagadnieniach. Po pierwsze - dotyczą one języka religii katolików na szeroko pojętych dawnych Kresach północno-wschodnich; po drugie wiążą się z osobą Floriana Czarnyszewicza, pochodzącego z Bobrujszczyzny autora kilku powieści, z których najbardziej znana, Nadberezyńcy, porównywana jest do Pana Tadeusza Adama Mickiewicza. Naszym zadaniem było zatem dotarcie do miejscowej parafii rzymskokatolickiej i zorientowanie się w sytuacji Kościoła katolickiego na tym terenie, liczebności wiernych oraz dystrybucji funkcjonalnej języka/języków w praktykach religijnych. Ponadto naszym zamiarem było skonfrontowanie obecnych realiów z rzeczywistością opisaną w powieści Czarnyszewicza - chodziło głównie o nazwy ojkonimiczne i antroponimiczne.

\section{Bobrujsk i okolice w przekroju historycznym}

Obecnie miasto leży po obu stronach rzeki Berezyny przy ujściu Bobrujki. Pierwsze wzmianki o Bobrujsku pojawiły się w źródłach pisanych dość późno mianowicie dopiero w 1387 roku w przywileju króla Jagiełły, na mocy którego województwo trockie wraz z przyległościami przekazywał on swojemu bratu Skirgajle [Ненадавец 1998: 9]. Stąd wniosek, że do tego czasu Bobrujsk nie wchodził w skład

* Artykuł ten w postaci skróconej został opublikowany w: „Lublin. Kultura i Społeczeństwo”, nr 6 (36) listopad-grudzień 2010, s. 93-101. 
Wielkiego Księstwa Litewskiego. Najprawdopodobniej został doń przyłączony dopiero w 1359 roku, kiedy Olgierd najechał księstwo smoleńskie i zdobył Mścisław, Posoże i Naddnieprze. W 1413 roku Bobrujsk został centrum starostwa, będącego częścią województwa wileńskiego. Starostowie, wywodzący się między innymi z takich rodów, jak Gasztołdowie, Glebowicze, Pacowie, Radziwiłłowie, Tryznowie, mieli siedzibę w zbudowanym w XVI wieku zamku [Чаропка 2010: 3]. Z racji położenia miasto często grabili i niszczyli Tatarzy krymscy i wojska moskiewskie (XVI wiek). Potem przez pewien czas rozwijało się pomyślnie i na początku XVII wieku liczyło około pięciu tysięcy mieszkańców, było w nim 15 ulic, 409 domów i 75 sklepów. Istniały już cerkwie św. Mikołaja i św. Ilji, a także Świętej Przeczystej. W 1618 roku rozpoczęli tu działalność jezuici, którzy przybyli z Nieświeża. W 1625 roku, przy poparciu wojewody Piotra Tryzny, jezuici zbudowali swoją rezydencję i kościół farny śś. Apostołów Piotra i Pawła (wcześniej, w roku 1615, Piotr Kazimierz Tryzna pobudował drewniany kościół, ufundowany przez Zygmunta III). Ponadto przekazał zakonnikom majątki Garbacewicze, Rynia, Ustajła [Ненадавец 1998: 21, 23]. Zakon prowadził tam działalność aż do swojej likwidacji [Słownik geograficzny Królestwa Polskiego: 266]. W latach 1630-1633 przełożonym domu zakonnego w Bobrujsku był Andrzej Bobola, nazywany Apostołem Polesia, zamęczony przez Kozaków w czasie powstania Chmielnickiego. Wtedy także (1648) Kozacy pod dowództwem atamana Poddubickiego, opanowawszy miasto, wymordowali zamożną szlachtę, ograbili kościół, po czym wspólnie z mieszczanami bronili się zaciekle przed oblegającymi wojskami litewskimi. Dopiero Janusz Radziwiłł zmusił ich do złożenia broni.

Podczas wojny polsko-rosyjskiej i potopu szwedzkiego Bobrujsk przechodził z rąk do rąk, między innymi miasto napadli kozacy hetmana Zołotarenki, którzy spalili i prawie doszczętnie wyniszczyli ludność polską i niemiecką.

W 1671 roku miasto liczyło zaledwie 170 domów. W 1682 roku król polski Jan III Sobieski nadał mu liczne przywileje, dzięki którym zaczęło podnosić się z upadku, ale już w 1708 roku znów ucierpiało po przemarszu wojsk rosyjskich i szwedzkich. Dodatkowo wyniszczyły je epidemie: w 1707 (cholery), 1709 i 1715 (dżumy). W 1741 roku w Bobrujsku było zaledwie 150 domów, powoli jednak, w dużej mierze za sprawą jezuitów ${ }^{1}$, miasto dźwigało się z ruin. Przy barokowym kościele zakonnicy zorganizowali szkołę, teatr, browar i pracownie stolarskie [Чаропка 2010: 3]. W 1793 roku miasto weszło w skład Imperium Rosyjskiego, jezuitów wypędzono, szkołę zamieniono na powiatową (gdy na mocy ukazu Katarzyny II z 1795 roku Bobrujsk stał się stolicą powiatu). Rok później nadano mu także herb - maszt z dwoma skrzyżowanymi drzewami, jako symbol miejscowych masztowych lasów, które wycinano, a pozyskane z nich drewno spławiano do Rygi.

W 1803 roku utworzono Wileński Okręg Oświatowy, w którego skład wszedł też Bobrujsk. Kuratorem tego okręgu został książę Adam Czartoryski. W szkołach

${ }^{1}$ W 1720 roku przy rezydencji jezuitów otwarto przytułek dla zbiedniałej szlachty [Ненадавец 1998: 33] 
Bobrujska i powiatu bobrujskiego językiem wykładowym był polski, ale nauczano też rosyjskiego [Ненадавец 1998: 41].

W 1832 roku utworzono Białoruski Okręg Oświatowy z centrum w Witebsku. W tym samym roku jezuici zakończyli swoją działalność w Bobrujsku. W 1840 roku w szkole powiatowej zniesiono język polski jako wykładowy [Ненадавец 1998: 78], a w 1862 także w trzyklasowym gimnazjum szlacheckim [Ненадавец 1998: 94]. Za to 20 sierpnia 1869 roku przywrócono język polski w kościele [Ненадавец 1998: 99].

Bobrujsk miał położenie strategiczne, toteż w obliczu ofensywy wojsk napoleońskich w roku 1810 rozpoczęto tu budowę twierdzy. Pomysłodawcą lokalizacji i częściowo autorem planów był Teodor Narbutt, generalnym autorem planów - Karol Operman. Przedsięwzięcie było ogromne, przewidywano, że w twierdzy będzie stacjonować 25 tysięcy wojska (według Słownika geograficznego Królestwa Polskiego - 14 tysięcy). Już w 1812 roku twierdza była gotowa. Podczas kampanii napoleońskiej bezskutecznie oblegała ją dywizja piechoty pod dowództwem generała Dąbrowskiego. W późniejszym okresie była miejscem zsyłki więźniów politycznych (karę odbywało tam między innymi kilku dekabrystów), uważanym za jedno z najstraszniejszych więzień.

O ile w twierdzy panował porządek i wręcz nowoczesność (w tym okresie należała do pierwszej klasy tego typu umocnień), o tyle w miasteczku - brud, ulice nie wysychały z błota nawet latem [Чаропка 2010: 12]. Dzięki usytuowaniu tu twierdzy Bobrujsk dość szybko otrzymał połączenie drogowe z Moskwą (1848 droga Moskwa-Warszawa) i kolejowe (1873) z Libawą (ob. łotewska Liepaja). Te komunikacyjne udogodnienia, a także spławna rzeka przyczyniły się do rozwoju handlu, który znajdował się głównie w rękach Żydów, powstawały też niewielkie fabryki (np. mydła, świec, wódek, piwa, miodu, cegielnie, cukrownia), na przełomie XIX i XX wieku było ich już 19. Wraz z rozwojem gospodarczym wzrastała też liczba ludności, pod koniec XIX wieku wynosiła ponad 37 tys. (w tym prawie 5 tys. liczył garnizon wojskowy). Niżej przedstawiamy dynamikę rozwoju ludności Bobrujska.

Mieszczanie zakładali też drukarnie, do miasta przyjeżdżały zespoły teatralne. W roku 1881 (od maja do września) i 1882 (latem) odbyły się 24 przedstawienia.

Od 1901 roku zaczęly się tworzyć grupy zwolenników „Iskry”, odbywały się zebrania poświęcone pamięci dekabrystów, bolszewicy organizowali nielegalne wiece młodzieżowe. W 1904 roku bobrujscy robotnicy po raz pierwszy obchodzili 1 maja jako święto pracy. Rok 1905 był dość burzliwy - dochodziło do strajków i demonstracji robotników, drukowano ulotki. Przez kolejne lata ruch rewolucyjny nasilał się: powstawały tajne organizacje partyjne, podziemne drukarnie, związki zawodowe.

W 1907 roku w Bobrujsku otwarto pierwszy kinoteatr, którego właścicielem był mieszczanin Fajnberg, zorganizowano 2-letnie kursy pedagogiczne, a w roku szkolnym 1907/1908 w bobrujskim gimnazjum żeńskim (Aleksiejewskim) wprowadzono klasę przygotowawczą i klasę ósmą (pedagogiczną). Miejscowa straż pożarna zorganizowała własną orkiestrę, w której grali głównie żydowscy chłopcy. Oprócz gry na instrumentach nauczano ich także języka starożydowskiego. Środki materialne na tę działalność dawali Żydzi [Ненадавец 1998: 134-135]. 
Tabela. Dynamika rozwoju ludności w Bobrujsku w latach 1800-1911

\begin{tabular}{|l|c|c|c|c|c|c|c|r|c|}
\hline $\begin{array}{c}\text { Płeć / narodowość / } \\
\text { wyznanie / zawód }\end{array}$ & $\mathbf{1 8 0 0}$ & $\mathbf{1 8 3 7}$ & $\mathbf{1 8 4 3}$ & $\mathbf{1 8 4 9}$ & $\mathbf{1 8 5 2}$ & $\mathbf{1 8 5 8}$ & $\mathbf{1 8 6 1}$ & $\mathbf{1 8 9 6}$ & $\mathbf{1 9 1 1}$ \\
\hline Ogółem w danym roku & 2180 & 10384 & 5701 & 31187 & 6222 & 26658 & 14145 & 33348 & 41361 \\
\hline Mężczyźni & 1093 & 5856 & 3063 & 27278 & 3137 & 15655 & 7143 & 19017 & 23166 \\
\hline Kobiety & 1087 & 4528 & 2638 & 3909 & 3085 & 11003 & 7002 & 14331 & 18195 \\
\hline Kupcy & 305 & 611 & 58 & 501 & - & - & - & 401 & - \\
\hline Duchowni & 32 & 34 & - & 22 & - & - & - & 95 & - \\
\hline Wolni obywatele & - & 9358 & - & 6077 & - & - & - & 22975 & - \\
\hline Wojskowi niskiej rangi & - & - & - & 23166 & - & - & - & 5601 & - \\
\hline Prawosławni & 319 & - & - & - & - & - & - & 11572 & 13210 \\
\hline Katolicy & 354 & - & - & - & - & - & - & 1931 & 1829 \\
\hline Protestanci & - & - & - & - & - & - & - & 21 & 385 \\
\hline Staroobrzędowcy & - & - & - & - & - & - & - & 500 & 508 \\
\hline Żydzi & - & - & - & - & - & - & - & 19125 & $25241^{2}$ \\
\hline
\end{tabular}

Źródło: materiały otrzymane w Muzeum Krajoznawczym w Bobrujsku.

W roku 1908 wyłożono brukiem pierwszą ulicę w Bobrujsku - ul. Murawjowa (ob. Socjalistyczna). Do roku 1914 wybrukowano jeszcze dwie. Pozostałe latem tonęły w kurzu, a jesienią i zimą w błocie, były czyszczone tylko przed wizytacjami gubernatora lub cara ${ }^{3}$. Latarnie gazowe oświetlały zaledwie kilka centralnych ulic. Jeśli dodamy do tego jeszcze fakt, że mieszkańcy przedmieścia Mińskiego i Berezyńskiego korzystali z wody rzecznej, do której nieco wyżej spuszczano ścieki z garnizonu i szpitala (częściowo też dowożono wodę pitną beczkowozami), otrzymamy obraz miasta brudnego i pełnego chorób (suchoty, szkarlatyna, odra, dyfteryt, dur brzuszny, dyzenteria) [Ненадавец 1998: 142].

${ }^{2}$ Bobrujsk słynął z dużego skupiska ludności żydowskiej. Na przełomie XIX i XX wieku Żydzi stanowili około 70\% mieszkańców miasta, choć nie brali czynnego udziału w jego życiu społeczno-kulturalnym. Raczej izolowali się od pozostałych grup narodowościowych. Zajmowali się rzemiosłem, handlem, lichwiarstwem, posiadali karczmy i domy zajezdne, byli dzierżawcami, kolejarzami. Większość z nich przybyła do miasta w poszukiwaniu pracy - szczególnie przyciągała ich praca w twierdzy (większość mieszkańców brała udział w jej zaopatrywaniu). Żydowska społeczność Bobrujska była jedną z największych i najbogatszych w Rosji - miała swoje synagogi, szkoły, szpitale, towarzystwa dobroczynne. Bogaci żydowscy przemysłowcy zakładali fabryki, tartaki, otwierali banki i sklepy. Jednak większość bobrujskich Żydów żyła w biedzie. Najbardziej znane nazwiska: historyk Samuel Łoziński, literat Izaak Nisenbaum, poeta Dawid Szymonowicz [Чаропка 2010: 16].

${ }^{3}$ Car Mikołaj I odwiedził miasto w 1916 roku w celu przeglądu wojsk - odbyła się parada wojskowa, wspólny obiad z żołnierzami oraz nabożeństwo w cerkwi [Ненадавец 1998: 145]. 
W 1910 w mieście zaczęła działać radiostacja. W latach 1911 (11 sierpnia) - 1912 (16 maja) ukazywała się gazeta „Бобруйские отклики” („Echo Bobrujskie”). Dwa lata później pojawił się „Бобруйский курьер” („Kurier Bobrujski”). Od 1916 roku pismo miało dodatek „Telegramy”, wychodziło do 9 listopada 1919 roku.

W roku 1913 w Bobrujsku funkcjonowało sześć gimnazjów: męskie (20 nauczycieli, 370 uczniów), Aleksiejewskie żeńskie (26 nauczycieli, 358 uczennic), prywatne męskie Hadyckiego-Ćwirko (19 nauczycieli, 281 uczniów), prywatne żeńskie Iljińskiej (26 nauczycieli, 323 uczennic), prywatne żydowskie żeńskie Łazarowej (12 nauczycieli, 218 uczennic), prywatne żydowskie żeńskie Jakiersberga (10 nauczycieli, 178 uczennic). Prawdopodobnie w niektórych gimnazjach odbywały się też lekcje języka polskiego, jednak nie było w mieście szkoły z polskim językiem wykładowym. Programy nauczania w szkołach męskich i żeńskich były różne - chłopcy po ukończeniu ośmiu klas gimnazjum mogli kontynuować naukę na uniwersytetach (ci, którzy ukończyli szkoły ze złotym lub srebrnym medalem, dostawali się na studia bez egzaminów); dziewczęta po ukończeniu siedmiu klas gimnazjum otrzymywały prawo do nauczania w szkołach początkowych, po ukończeniu klasy ósmej (pedagogicznej) mogły pracować jako nauczycielki domowe, otrzymywały też prawo wstępu na wyższe kursy bez egzaminów [Ненадавец 1998: 141]. 15 października 1917 roku otwarto Szkołę Artystyczną Rysunku, Malarstwa i Sztuki Dekoracyjnej. Odbywały się w niej wykłady z historii sztuki, anatomii, perspektywy. Zapisy prowadzono między innymi w Domu Polskim przy ul. Romanowskiej [Ненадавец 1998: 147].

W roku 1914, po wybuchu I wojny światowej, w Bobrujsku i okolicach przeprowadzono nabór rekrutów, sformowano z nich dwa pułki piechoty. Zorganizowano warsztaty, których zadaniem było zabezpieczanie potrzeb frontu. W tym samym okresie zanotowano pierwsze grabieże majątków ziemskich przez chłopów białoruskich. Oto fragment Nadberezyńców, oddający atmosferę tych czasów:

Ale chłop porwany wyścigiem rabunku, stał się jak ten byk w walce rozjuszony, albo rozwścieczony pies: ślepy na czyny, głuchy na upomnienie, nieczuły na litość, o którą go las swym jękiem zdawał się błagać! [grabieże zaczęły się od masowej wycinki „pańskich” lasów - M. O.] Walił, znaczył, pustoszył, aż w końcu nadarzył się korzystniejszy przedmiot rabunku.

[...] żal się takim zrobiło, iż po trzechletniej walce za ojczyznę na równi z majętnymi, oni przy nich w życiu prywatnym znów pozostają nędzarzami. [...] Burżuje muszą podzielić się z nimi swym chlebem. [...] zbierali się w gromady [...] brali karabiny, które przynieśli wracając z wojska, strzelby, widły, drągi i szli zbrojnym tłumem do dworów na „rekwizycje”; rabowali, dzielili między siebie ziarno, snopy, bydło, owce, świnie i wszelaki inny dobytek. [...]

Zapoczątkowany rabunek przez jedną wieś, zachęcał inną, przenosił się z dworu do dworu, obejmował kraj cały, przechodził w mord, pożogę, pogrom [Czarnyszewicz 2010: 203-204].

W 1917 powstały organizacje partyjne - bobrujski komitet Rosyjskiej Socjaldemokratycznej Partii Robotniczej, Komitet Tymczasowy, później przemianowany 
na Radę Deputatów Robotniczych i Wojskowych. Na przełomie maja i czerwca 1917 roku w zakładach przemysłowych miasta wprowadzono ośmiogodzinny dzień pracy.

Latem 1917 roku na Białorusi zaczęły się tworzyć oddziały wojska polskiego. Początkowo składały się z Polaków - żołnierzy armii carskiej, później dołączyli do nich przeważnie młodzi chłopcy z Bobrujszczyzny. Oddziały te skupiły się w I Korpusie Polskim pod dowództwem gen. Józefa Dowbór-Muśnickiego, który wykształcenie wojskowe zdobył w rosyjskiej Nikołajewskiej Akademii Sztabu Generalnego w Petersburgu ${ }^{4}$. Już po kilku miesiącach Korpus liczył około 50 tys. żołnierzy. Początkowo byli oni rozkwaterowani w dworach i zaściankach szlacheckich kilku guberni. Później - od lutego 1918 roku - wszystkie jednostki skoncentrowały się w Bobrujsku i okolicach, gdzie walczyły z bolszewikami, chroniły polską ludność przed pogromami chłopskimi. Groziło to nawet ich przeobrażeniem w siły policyjne, jak chciała tego Rada Polska Ziemi Mińskiej. Stanowczo sprzeciwił się temu Józef Dowbór-Muśnicki, który nie chciał sprowadzić I Korpusu do roli strażników i obrońców majątków ziemskich. Mimo wszystko polscy żołnierze niejednokrotnie bronili ich przed grabieżą, co dodatkowo pogarszało stosunek białoruskich chłopów do Polaków.

Ludność polska z entuzjazmem witała wojsko polskie. W jej serca wstąpiła nadzieja na przyłączenie terenów nadberezyńskich do niepodległej Polski. Oto cytat z powieści Floriana Czarnyszewicza ${ }^{5}$ Nadberezyńcy, ukazujący uczucia Polaków witających polskie oddziały w Bobrujsku:

Jakoż wychodząc na róg Puszkina, dosłyszał niedaleko z boku śpiew żołnierski. Kościk tak lubował się w marszu i śpiewie wojska, iż mimo niepokoju, jaki go trapił, zatrzymał się i słuchał patrząc w stronę, z której dochodził.

Melodia była nadzwyczaj miła, porywająca i jakby - nie sołdacka.

Niebawem ustała i w pół minuty zaczęło się wyłaniać czoło oddziału piechoty. Zawracało ku niemu. Z karabinami.

Liczył czwórki. - Trzydzieści pięć wszystkich było. - Za ostatnią ujrzał ku pewnemu zdziwieniu - tłum cywilów.

Oddział wyrównał się w cztery struny i gruchnął pieśń. [...]

Kościk osłupiał ze zdumienia: nie wierzył swym uszom i oczom.

${ }^{4}$ Najsilniejszy, liczący ponad 20 tys. oficerów i żołnierzy I Korpus Polski z generałem Józefem Dowbór-Muśnickim na czele powstał w połowie 1917 na terenie Białorusi. Na przełomie 1917 i 1918 roku I Korpus wdał się w walki z oddziałami rewolucyjnymi. Generał Dowbór-Muśnicki zawarł umowę z Niemcami, na mocy której I Korpus Polski otrzymał status jednostki pomocniczej armii niemieckiej. Umowa nie przeszkodziła Niemcom rozbroić polskiej jednostki w maju 1918 roku, gdy polskie wojsko przestało być potrzebne [http://portalwiedzy.onet.pl/14102....korpusy_polskie,haslo. html] 17.01.2011.

${ }^{5}$ Czarnyszewicz jako dziewiętnastoletni chłopak uczestniczył w walkach z bolszewikami, był także wywiadowcą, co w powieści odzwierciedlają losy Stacha Bałaszewicza - alter ego autora. 
- Po polsku?!... Jezusie!... Śnię-że to ja, czy na jawie słyszę?! Polskie wojsko!... szeptał utkwiwszy wzrok w szeregi.

Buty, spodnie, bluzy i karabiny, jak u zwykłej ruskiej piechoty, ale na głowach maciejówki, a na nich orzełki polskie. I słowa płyną z ust polskie. Twarze młode, dziarskie, dumne.

- Równaj!... Raz, dwa, trzy! Raz, dwa, trzy! - podaje oficer komendę. Sto czterdzieści butów grzmi jak jeden, jak jeden kołysze się sto czterdzieści bagnetów. Rzekłbyś szczotka. [...]

Z tyłu postępował tłum miejscowych Polaków, dusz sto. Niektórzy, aby okazać legionistom szacunek, zdjęli czapki, wielu wrażliwych płakało ze wzruszenia.

- Ot, czego doczekali my! - mówiono. - Swoich polskich sołdatów. Po polsku śpiewają! Nie try, ale trzy mówią. Słuchajcie, ludcy rodzone, słuchajcie!... [Czarnyszewicz 2010: 136-137].

- Wojsko?!... Polskie?!... - zdumiał się [dziadek Kazika, stary Zdanowicz]. - Co ty pleciesz? [...] Starcowi oczy zaszły łzami, wargi zaczęły drżeć i kurczyć się jak rozżalonemu dziecku.

- Po polsku śpiewają... szeptał. - Sama sobą będzie... To nie może być! Zapewne tak samo wyjdzie jak z tym manifestem. Nie, nie wierzę. Boże! - wzniósł oczy ku niebu - daj mi pożyć jeszcze... [Czarnyszewicz: 140].

Po podpisaniu ugody z Niemcami Dowbór-Muśnicki, nie uzyskawszy poparcia Rady Regencyjnej, został zmuszony do złożenia broni i powrotu do Polski. Tym samym Bobrujsk znalazł się w rękach niemieckich. W listopadzie 1918 roku Armia Czerwona odbiła miasto. Niecały rok później - w sierpniu 1919 Bobrujsk zajęły ponownie wojska polskie i pozostały tam do lipca 1920 roku. Twierdza posłużyła wtedy jako obóz jeniecki dla czerwonoarmistów [Аўсейчык 2010: 21].

Traktat ryski (1921) na zawsze udaremnił plany i marzenia Polaków. Białoruś Wschodnia pozostała w granicach Rosji Sowieckiej. Aby uniknąć represji, uczestnicy wojny polsko-sowieckiej 1919-1920 (wśród nich Czarnyszewicz) i bogatsi właściciele ziemscy opuścili strony rodzinne razem z wojskiem polskim.

W czasach radzieckich Bobrujsk znacznie się rozwinął. Twierdza nadal służyła wojsku. W latach sześćdziesiątych i siedemdziesiątych zasypano część suchych fos. Obecnie jest w stanie postępującej ruiny, choć niektóre obiekty zostały odnowione i prawdopodobnie istnieją plany dalszej rekonstrukcji.

Według danych spisu ludności z roku 1923 Bobrujsk liczył 36656 mieszkańców: 19619 Żydów, 11341 Białorusinów, 2355 Rosjan, 1502 Ukraińców, 910 staroobrzędowców, 451 Polaków, 21 Tatarów, 110 nieznanej narodowości, 451 innych. W 1932 roku miasto liczyło już 62300 mieszkańców, w tym 40000 Żydów, a w 1939 roku 84107 ludności [Маліноўскі 2008: 79], natomiast po zakończeniu II wojny światowej niewiele ponad 28 tysięcy. Z 7650 domów ponad 3000 spłonęło lub zostało zburzonych. Obecnie Bobrujsk liczy 215092 mieszkańców. Białorusini stanowią 83,06\%, Rosjanie 13,22\%, Ukraińcy 1,89\%, Żydzi 0,27\%, Polacy 0,27\%, inni 1,29\%, [w:] http://beold.wikipedia.org/wiki 18.01.2011 


\section{Kościół katolicki na Bobrujszczyźnie w XX i XXI wieku}

Pod rosyjskimi rządami katolicy na ziemiach dawnej Rzeczypospolitej nie mogli swobodnie budować świątyń, dlatego pożar parafialnego kościoła pod wezwaniem śś. Piotra i Pawła w Bobrujsku, do którego doszło w 1902 roku, był dla społeczności katolickiej prawdziwym dramatem. Jednak w 1905 roku polityka wobec katolików stała się bardziej liberalna, toteż dzięki staraniom księdza Jana Krasowskiego, ze składek parafian, rozpoczęto budowę nowego neogotyckiego kościoła pod wezwaniem Niepokalanego Poczęcia Najświętszej Maryi Panny [Kościół 1999: 188; Маліноўскі 2008: 72]. Świątynię wyświęcono w 1906 roku. Parafia liczyła 6000 wiernych, rozrzuconych po dużym obszarze wokół Bobrujska. Należały do niej również Osipowicze i dziesięć kaplic nawiedzanych regularnie przez proboszcza i wikarych [Kościół 1999: 188].

Pomimo przemian politycznych nabożeństwa w kościele bobrujskim odprawiane były do 1935 roku. Jednak wcześniej, w roku 1922, kościół rzymskokatolicki - podobnie jak inne świątynie Bobrujska - ogołocono z wszelkich kosztowności. W roku 1934 kościół zamknięto, a duchownym zabroniono wykonywania posługi. W 1937 został aresztowany bobrujski proboszcz, ksiądz Feliks Wyliżyński, a w budynku świątynnym urządzono wystawę osiągnięć rolnictwa. W roku 1939 represje osiągnęły apogeum - zamknięto prawie wszystkie kościoły, a w dziesięciu formalnie działających nie było księży. Wielu z nich rozstrzelano lub zaginęli w więzieniach i łagrach [Kościół 1999: 81].

Trzyletni okres okupacji hitlerowskiej był czasem ponownego otwarcia kościoła. Funkcję proboszcza pełnił ksiądz niemiecki, z więzienia wyszedł dawny proboszcz, ksiądz Feliks Wyliżyński i również pełnił posługę duszpasterską. Jednak wraz z wkroczeniem Armii Czerwonej w czerwcu 1944 roku ten okres się zakończył. Ponownie zamknięto kościół i zabroniono sprawowania nabożeństw. W tym samym roku zmarł ksiądz Feliks Wyliżyński, pochowano go najpierw obok kościoła, a w roku 1967 przeniesiono na cmentarz przy ulicy Mińskiej. Jego grób stał się w czasach radzieckich miejscem spotkań modlitewnych katolików Bobrujska.

W tych czasach wierni, aby uczestniczyć w eucharystii i innych sakramentach, udawali się na Litwę, do Wilna. Stamtąd przywożono czasem księży. Spotkania modlitewne i nabożeństwa, jeśli obecny był kapłan, sprawowano w prywatnych domach. Gospodarze takich spotkań narażeni byli jednak na dotkliwe kary. Julia Ślaz [Слязь] zapłaciła za udostępnianie swojego domu rokiem więzienia. W pamięci parafian zachowało się wspomnienie o sile jej charakteru, którego nie złamało nawet więzienie.

Od drugiej połowy lat pięćdziesiątych na Bobrujszczyznę przyjeżdżali księża z Grodzieńszczyzny i Litwy.

W 1988 roku z pieniędzy wiernych, głównie osób starszych, kupiono dom przy ulicy L. Czajkinej [Чайкінай] i oficjalnie zarejestrowano go jako dom modlitwy 
wspólnoty rzymskokatolickiej. W 1989 roku parafianom oddano kościół [Kościół 199: 86]. Oto jak wspomina te czasy nasza informatorka:

(Где вы молились, когда не было ксендза) Da, domik był malitwiennyj. Kupili, katoliki sabrali sia i kupili domik i chadzili tuda malilisia. Malilisia. No skolko eto hadou było ja tak nie pomniu, no ja znaju szto ja chadziła tuda hod. Chacieła nauczycsa malicsa, patamu szto ja znała Otcze nasz Zdrovaś Maryja wot Wierzeń w Boga Ojca. Astalnoje dumaju no chodźby i czytać nauczyłasia, no dyk uże toże i rabotała, i dzieci, i chaciełosia. Każdoje waskriesieńje jeździła w etot domik wmieście, wmieście s etoj siestroj i malilisia. A patom uże dziewianostyje hody atkryli u Babrujskie [kaścioł], ja koje-szto znała. No ja wot nie znaju, eta uże on [domik] dołżen był kaściołu prynadlieżyć. Tak ci on ani padali, no ja eta nie znaju, no eto uże pajdziot koniecznie, chot' i nie padali. Eto dlia kaścioła uże budziet i patom nawierno dwie żenszczyny umirali i svaje kvartiry zawieszczali kaściołu.

W kolejnych latach głównym zadaniem proboszcza było z jednej strony wyremontowanie kościoła, a $\mathrm{z}$ drugiej praca wśród wiernych, z których wielu przez lata nie przystępowało do sakramentów.

Obecnie parafia liczy około 2000 wiernych. Do dekanatu bobrujskiego należy także filia w Hłusku, gdzie w nabożeństwach uczestniczy 150 osób, i w Kliczewie - 100 osób. W Bobrujsku w niedzielę odprawiane są trzy msze święte: dwie po białorusku, jedna po polsku.

\section{Sytuacja językowa na badanym terenie}

Wiadomości na temat ludności polskiej w Bobrujsku i okolicach od traktatu ryskiego do czasów obecnych nie mamy. Najprawdopodobniej tych, którzy posiadali własną ziemię i zostali zakwalifikowani jako kułacy, deportowano, podejrzanych o współpracę z polskim wojskiem zapewne skazano na karę śmierci (rozstrzelano). Wprawdzie, zgodnie z zasadami polityki leninowskiej, przez pewien czas po rewolucji październikowej każda narodowość mogła się swobodnie rozwijać - miała prawo do obsługi administracyjnej we własnym języku, organizowano więc polskie rady wiejskie (sielsawiety). Wobec ogromnej skali analfabetyzmu wprowadzono obowiązkowe kształcenie dzieci w języku ojczystym - masowo powstawały polskie szkoły, domy dziecka, izby-czytelnie, punkty likwidacji analfabetyzmu dla dorosłych, czyli tzw. likpunkty itp. Tworzono je na podstawie postanowienia Ludowego Komisariatu Oświaty z 1918 roku, zgodnie z którym było to możliwe „wszędzie tam, gdzie istnieje wystarczająca liczba uczniów danej narodowości dla otwarcia szkoły". Minimalną liczbą było 25 dzieci w jednym wieku [Iwanow 1991: 178]. Nowy radziecki system szkolny, tzw. gławnoje socjalnoje wospitanije (gławsocwos), którego projektodawcą był Anatolij W. Łunaczarski, zaczęto wprowadzać w życie po 1921 roku. System ten obejmował szkolnictwo podstawowe i średnie, nauka trwała 9 lat 
i była podzielona na dwa szczeble: I - dla dzieci w wieku 8-13 lat i II - dla dzieci od 13 do 17 lat [Zasztowt 1997: 252].

Poniżej przedstawiamy wykaz szkół powiatu bobrujskiego z lat 1923/24, sporządzony na podstawie sprawozdania CPBO [Centralne Polskie Biuro Oświatowe] z marca 1924 roku $^{6}$ (uczyło się w nich 717 uczniów, a wykładało 15 nauczycieli) ${ }^{7}$ :

1. gm. gorodkowska - Huta III Międzynarodówki - 4 komplety - 3 nauczycieli,

2. gm. bacewicka - Olgino-Dubrowka - 4 komplety - 2 nauczycieli,

3. gm. paryczewska - Lipniki - 4 komplety - 1 nauczyciel,

4. gm. paryczewska - Szaciłowo - 4 komplety -2 nauczycieli,

5. gm. scieńska - Zamień-Ryżesk - 4 komplety - 1 nauczyciel,

6. Oktjabr - Oktjabr - 4 komplety - 2 nauczycieli,

7. gm. czyczeryńska - miasteczko Osipowicze - 4 komplety - 1 nauczyciel,

8. gm. brożska - szkoła Prodwińska 4 komplety - 1 nauczyciel,

9. gm. bacewicka - szkoła Stefanowska - 4 komplety - 1 nauczyciel,

10. gm. gorbacewicka - szkoła Borska - 4 komplety - 1 nauczyciel,

11. gm. gorbacewicka - Omeljanow most - 4 komplety - 1 nauczyciel.

Polska oświata na Białorusi, mimo braków kadrowych i lokalowych, rozwijała się jednak tylko do momentu zakończenia radzieckiego eksperymentu polonijnego. Z chwilą wszczęcia represji w stosunku do ludności polskiej (ok. 1933) rozpoczęto także likwidację polskich szkół, którą zakończono w 1938 roku. Wówczas wszelkie przejawy polskiego patriotyzmu były traktowane jako polski nacjonalizm i groziły wywózką lub rozstrzelaniem. O skali zjawiska świadczy niewielki pomnik na cmentarzu w Prodwinie, poświęcony ofiarom represji politycznych rozstrzelanym w latach 1937, 1938, $1940^{8}$.

Społeczność polska na Bobrujszczyźnie, podobnie jak i na całej Białorusi radzieckiej, ulegała postępującej dezintegracji i asymilacji. Już w dwudziestoleciu międzywojennym zawierano coraz więcej małżeństw mieszanych, a brak czynnego kościoła spowodował powszechność związków cywilnych. Dzieci posyłano do szkół białoruskich, polszczyznę, nawet jeśli była językiem domowej komunikacji, stopniowo wyparła gwara białoruska, język rosyjski lub tzw. trasianka.

${ }^{6}$ Więcej na ten temat między innymi w książce: I. Grek-Pabisowa, M. Ostrówka, B. Biesiadowska-Magdziarz, Historia i współczesność języka polskiego na Białorusi Wschodniej. Polszczyzna pisana, Warszawa 2008.

7 Źródło: NARB f. 4, op. 11, dz. 9, s. 34, 34 ob (Narodowe Archiwum Republiki Białorusi / Nacyjanalny Archiu Respubliki Biełaruś): zespół (fond) - f.; inwentarz (opis) - op.; sprawa (dieło) dz.; strona s.; skrót ob (oborot) oznacza, że informacja znajduje się na odwrocie karty.

${ }^{8}$ Nazwiska uwidocznione na pomniku zapisano po rosyjsku - tu podajemy łacinką. Boki Aleksander, Boki Ignacy, Boki Józef, Boki Aleksander, Boki Flerka, Bołbas Roman, Swierż Kozimir, Swierż Feliks, Jankowski Aleksander, Jankowski Fiodor, Jadłowski Staś, Gowarowski Albert, Sokołowski Konstanty, Korotkiewicz Piotr, Swierż Franc. 


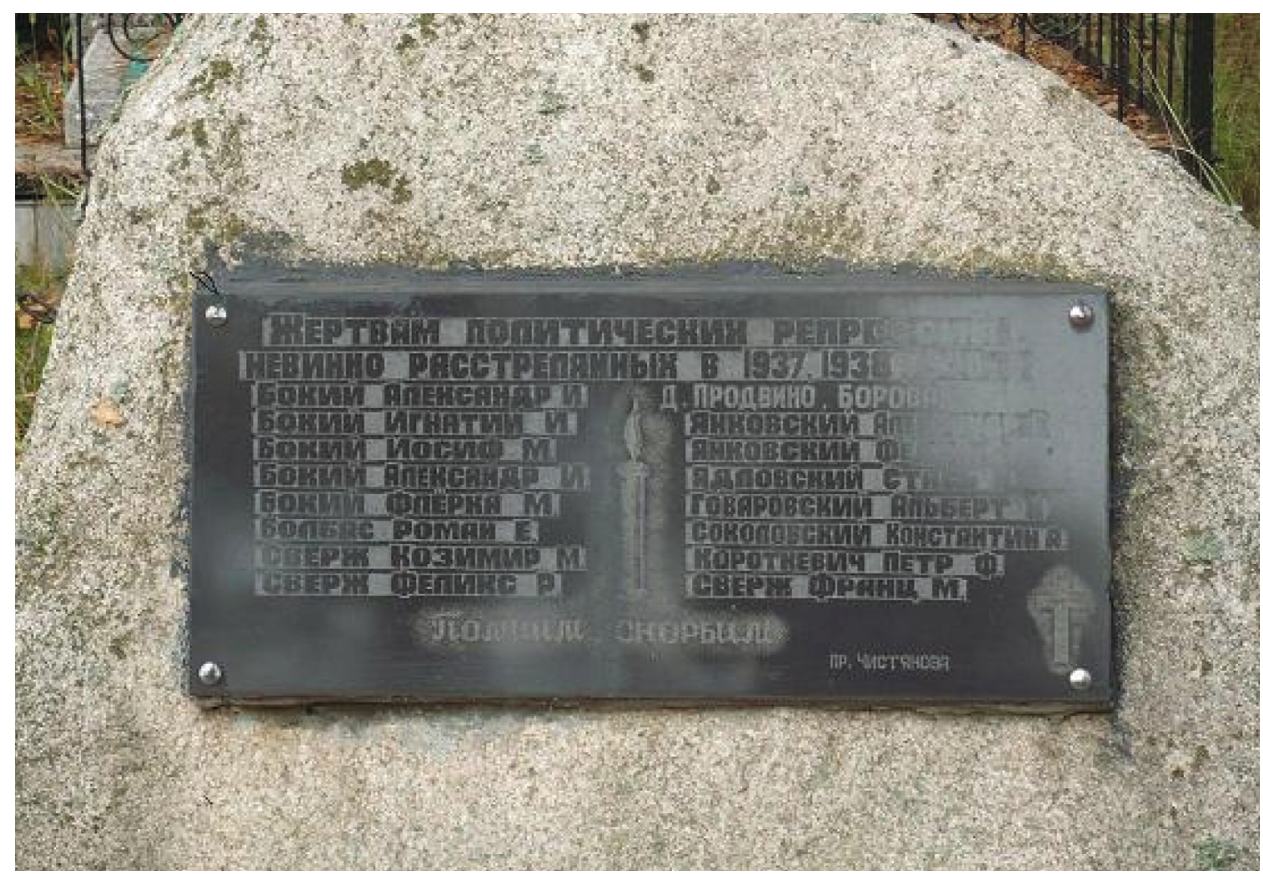

Fotografia pomnika ofiar represji politycznych w Prodwinie

Częściowy obraz sytuacji socjolingwistycznej tuż przed II wojną światową uzyskałyśmy od naszej informatorki ze wsi Prodwino (oddalonej od Bobrujska o kilkanaście kilometrów), Franciszki Żurowej, z domu Wiszniewskiej, urodzonej w 1935 roku. Z jej relacji, a także z napisów nagrobnych na miejscowym cmentarzu można wysnuć wniosek, że mógł to być zaścianek szlachecki, ponieważ jej mieszkańców sąsiednie wsie nazywały szlachtą, a na cmentarzu powtarzają się nazwiska: Boki (13), Jadłowski (2), Osiecki (6), Wiszniewski (3), Swierz (3), Tracewski (3). Za szlacheckimi korzeniami mieszkańców przemawiają też fotografie na nagrobkach - kobiety o wymienionych wyżej nazwiskach nie mają na głowach chustek, lecz fryzury ułożone w loki i suknie z białymi kołnierzykami. Mężczyźni ubrani są w garnitury i mają podkręcone wąsy. Informatorka potwierdziła to także w czasie rozmowy:

(А может вы происходите из иляхты??) No nawierno tak. No papa nasz, jaż hawaryła, on wa wriemja wajny pahip, a my byli malieńkije. A możet szto i hawarył, no nie pomniu, a patom jewo zabrali na wajnu i on pahip, wot, no a mama możet szto i hawaryła, dak pazabywali, ni abraszczali asobaha wnimańja.

Rdzenną mieszkanką Prodwina była matka informatorki - Sabina Feliksowna Wiszniewska, z domu Boka. Ojciec Feliks pochodził z jednej z sąsiednich wsi. Przed rewolucją październikową kandydatów na męża/żonę poszukiwano nawet 
w dalszej okolicy - dowiadywano się, w jakiej miejscowości mieszkają „porządni” katolicy mający pannę lub kawalera, i posyłano swaty.

Domowym językiem w rodzinie Wiśniewskich była właśnie mieszanka rosyjskiego i białoruskiego. Babcia prawdopodobnie mówiła po polsku, ale wcześnie umarła. Ilustruje to cytat:

Eto i był biełaruskij wmieście s ruskim [...] a my, uże mama rabotała, kołchoz był, zabota. Pa polski uże asoba nie było kagda uczyć w jejo - rabota, rabota. [...] Babuszka, ana umierła, ana hawaryła pa-polski kaniesznie, no ja etaha nie pomniu, no ana razhawarywała pa-polski. A dzieduszka waapszcze rana umier, wot a babuszka razhawarywała s etaj doczkaj swajej.

Siostra matki mieszkała w mieście i ze swoją córką rozmawiała po polsku:

A mamina siestra u gorodzie żyła, wot eta [...] u niejo doczka była Ała. Ana razhawarywała na polskom jazykie, siestra mamina.

Informatorka ukończyła siedem klas szkoły białoruskiej, co dodatkowo wpłynęło na utratę języka:

Abszczalisia na biełaruskom i szkoła była [biełaruskaja] czetyrie a patom [tri] siem ja zakończyła, siem [kłassow].

Zgodnie z dotychczasowymi obserwacjami dotyczącymi funkcjonowania języka to właśnie środowisko wiejskie, jako odizolowane od wpływów zewnętrznych, sprzyjało jego zachowaniu. W Prodwinie mamy sytuację odwrotną - krewne mieszkające $\mathrm{w}$ mieście posługiwały się polszczyzną, a mieszkanki wsi rozmawiały ze sobą mieszanką gwary białoruskiej i rosyjskiego. Można snuć przypuszczenia, że język polski nie był językiem domowym już w pokoleniu babci informatorki. Tego, że mieszkając z siostrą matki w Bobrujsku, rozmawiały między sobą po polsku, trudno dowieść. A może większa anonimowość życia miejskiego pozwalała na rozmowę w domu po polsku? Środowisko wiejskie takiej anonimowości nie dawało - tam każdy wiedział o sąsiedzie prawie wszystko. Przymusowa praca w kołchozie, gdzie oprócz miejscowych zawsze pracowali przybysze z Rosji lub innych republik, także sprzyjała asymilacji - należało porozumiewać się w ogólnie zrozumiałym języku. Kobiety, zatrudniane zwykle do pracy przy inwentarzu żywym, najczęściej jako dojarki, nie miały czasu na zajmowanie się dziećmi i uczenie ich języka innego niż ogólnie przyjęty. Pozostał on jedynie w sferze praktyk religijnych, o czym będzie mowa niżej.

Dziś prawie nie można już odnaleźć śladów przedwojennych stosunków społeczno-kulturalnych w Bobrujsku i okolicach. Zresztą trudno wyciągać ogólniejsze wnioski po jednym krótkim wyjeździe badawczym. Jak już wspomniano, nastąpiła prawie całkowita asymilacja. Nie spotkałyśmy miejscowych osób identyfikujących się z polskością czy też mówiących po polsku. Nasi informatorzy potwierdzili, że 
wśród rodowitych mieszkańców nie ma już osób polskojęzycznych, a ci, którzy władają choćby w małym stopniu polszczyzną, pochodzą z Białorusi Zachodniej.

Nowym zjawiskiem, znanym nam już z Grodzieńszczyzny, jest uczenie się polskiego przez młode pokolenie. Wzorem jest tu polszczyzna w wersji standardowej, która wchodzi $\mathrm{w}$ interferencje $\mathrm{z}$ językiem białoruskim i rosyjskim na wszystkich poziomach. Wprawdzie w Bobrujsku nie ma obecnie żadnych kursów języka polskiego, ale poprzedni proboszczowie sprzyjali nauce polskiego podejmowanej indywidualnie przez młode osoby związane z kościołem ${ }^{9}$. Niestety, nawet tych osób nie ma obecnie w Bobrujsku, ponieważ pracują w Mińsku.

Tak więc sytuacja socjolingwistyczna przedstawia się następująco: w mieście językiem prymarnym jest rosyjski z elementami białoruskiego. Język ten wykazuje duże zróżnicowanie idiolektalne. Na wsi wśród osób, które całe życie z niej nie wyjeżdżały, usłyszeć można jeszcze gwarę białoruską (co potwierdza zasadę, że mieszkanie na wsi sprzyja jej zachowaniu). Polszczyzna obecna jest jedynie w liturgii i modlitwach najstarszego pokolenia. Na odprawianych po polsku mszach świętych polska jest liturgia słowa, natomiast kazanie i ogłoszenia duszpasterskie w języku białoruskim. Liczna obecność wiernych świadczyć może o przywiązaniu do języka polskiego jako języka liturgii. Potwierdzają to relacje naszych informatorów - wiemy, że czytają polskie modlitewniki i Pismo Święte. Ilustruje to następujący cytat:

Wot u mienia papina biblija jeszczo astałas', wam pakażu. U mamy byli staryje, staryje książeczki, dak my razdzielili mieżdu saboj i mnie papała eta biblija, a trom siostram toże pa malitwieńniku. I vot ja zimoj, cipier ja mała czytaju, a zimoj, kak naczynajetsa dyk ja czytaju. [bukwy] malieńkije, no poka ja poka wiżu, no pańjatnaja eta pańjatnaja takaja biblija pańjatnaja, mamina wsio.

Na badanym terenie nie ma też polskiej organizacji społeczno-kulturalnej. Przez trudny do określenia czas działał tu prawdopodobnie oddział Związku Polaków na Białorusi, ale z chwilą śmierci ostatniej ze starszych jego członkiń figuruje tylko na stronie internetowej miasta Bobrujsk. Rozmawiałyśmy z osobą uważaną przez lokalne władze za przewodniczącego ZPB, który twierdzi, że nie ma organizacji, ponieważ nie ma chętnych nawet do zapisania się do niej, nie mówiąc już o jakiejkolwiek działalności, co ilustruje cytat:

Zdies' niet dawlienija Poliak, Biełarus, Russkij, absaliutna. I liudzi nie widziat nieabchadimosti [...] liudzi tierjajut korni, nacjanalnas't'.

Młodzi, obserwując ostatnie wypadki związane z działalnością ZPB na Białorusi, zdystansowali się od niego. Przewodniczący uważa, że dużą rolę gra tutaj

9 Obecny proboszcz ma zdecydowanie białoruską identyfikację, ale biegle mówi po polsku. 
komercyjne i pragmatyczne podejście młodszego pokolenia (czyli: „Szto mnie dast Sajuz Paliakow?”, jakie będę miał wymierne korzyści). Sądziłyśmy, że pewnym magnesem mogłaby być Karta Polaka. Okazuje się jednak, że informacje na temat jej uzyskania są skąpe i w Bobrujsku trudno dostępne. Do tego należy dodać brak wymaganej do uzyskania Karty przynajmniej podstawowej znajomości języka polskiego. Ciekawostką, paradoksalnie, jest fakt, że przewodniczący sam zna polski tylko w stopniu biernym, tzn. czyta polskie teksty związane $\mathrm{z}$ jego hobby - numizmatyką. Posiada znaczne zbiory polskich monet od czasów najdawniejszych po obecne i dość gruntowną wiedzę z historii Polski. Ponadto on, jego żona i dzieci są wyznania prawosławnego, ale jego pradziadek był Polakiem i katolikiem. Uczestnicząc w różnych uroczystościach katolickich, stwierdził, że bardziej podobają mu się obrzędy katolickie:

[...] katolik był pra-pradzied, da, dzied Antoś. A uże pradzieda siem’ja była balszaja, on zapisał - eta period riewaliucyji - i on zapisał [...] biełarusam [...]. Wot na dannyj mamient ja prawasławnyj, no kataliczieskije abriady mnie bolsze bliże [...] maja siestra [...] ani wienczalis' w kastiolie - kataliczieskij abrjad krasiwieje, łuczsze. Bolieje poniatien.

(А как вы воспитали своих детей?) Russkojazycznyje. Kries'c'ili, wsio tradicionna. Ano prachodit pa radstwu pravasławje.

Uważa, że jeśli Polska będzie zwracać większą uwagę na sprawę odrodzenia kultury i oświaty w Bobrujsku, a kościół będzie oddziaływał na miejscową społeczność przynajmniej tak jak do tej pory, ludzie, mając wybór, będą zwracać się ku polskości i katolicyzmowi. Pytany o funkcjonowanie języka polskiego na wsi, stwierdził, że będąc dzieckiem (urodził się w 1941 roku), spędzał wakacje na wsi. W sąsiedztwie mieszkali przedstawiciele różnych narodowości, słychać było język polski, białoruski, rosyjski. Po dwóch tygodniach pobytu w rodzinnej miejscowości matki mówił płynnie gwarą białoruską (oboje rodzice posługiwali się językiem białoruskim). Obecnie nawet na wsi trudno już usłyszeć białoruski. Z czasem utracił on białoruski na rzecz rosyjskiego i taki proces zachodził u każdego, kto na stałe wyjeżdżał ze wsi do miasta.

To samo mówiły nasze informatorki - spośród trzech sióstr tylko najstarsza, która nigdy nie wyjeżdżała z rodzinnej miejscowości, zachowała najwięcej cech białoruskich. Dwie młodsze posługują się językiem rosyjskim z cechami białoruskimi.

\section{Napisy nagrobne w Bobrujsku i okolicach}

Cennym źródłem do badania sytuacji socjolingwistycznej są także napisy nagrobne. Analiza napisów cmentarnych - alfabetu, dat, szyku imienia i nazwiska, obecności imienia/imion rodziców czy też dodatkowych inskrypcji - pozwala na uzupełnienie danych dotyczących składu narodowościowego i wyznaniowego 
miejscowości/parafii (przy czym na Bobrujszczyźnie jest to dość trudne, ponieważ większość napisów jest w cyrylicy). Można też określić cechy językowe społeczności, której członkami były osoby pochowane na danym cmentarzu. Analizą inskrypcji nagrobnych na byłych Kresach północno-wschodnich zajmowało się dotychczas kilku badaczy, są to między innymi (w kolejności chronologicznej): Wiaczesław Werenicz [1989, 1993, 2001], Jadwiga Kozłowska-Doda [1997, 2000], Irena Maryniakowa [2001], Anna Stelmaczonek [2002], Halina Karaś [w druku].

Podczas wyjazdu badawczego zwiedziłyśmy cztery cmentarze, gdzie sfotografowałyśmy 87 nagrobków: w Izjumowie (dawniej Durynicze - 6), Domanowie (27), Prodwinie (31) i w Bobrujsku (23) ${ }^{10}$, co do których miałyśmy pewność, że pochowane $w$ tych grobach osoby były Polakami (wskazywało na to nazwisko, imię lub imię ojca). Z tej liczby 33 inskrypcje zostały wyryte alfabetem łacińskim, czasami, szczególnie w miejscowościach wiejskich, nastąpiło pomieszanie czcionki łacińskiej z cyrylicą lub też liter wielkich i małych.

Sposób zapisu nazw osobowych związany jest z przedziałem czasowym, w którym dana osoba żyła. Napisy na grobach osób urodzonych około połowy XIX wieku, a zmarłych w latach 1900-1926, mają polski szyk, czyli „imię + nazwisko + (czasami) imię ojca/imiona rodziców/nazwisko rodowe". W Izjumowie tak jest na wszystkich sfotografowanych grobach (6) - trzy z nich znajdują się w kaplicy i należą do rodziny Zabiełłów. Te, które znajdują się na cmentarzu, są praktycznie nie do odczytania - widać tylko fragmenty zapisu, co jednak pozwala określić język i schemat. W Domanowie są cztery nagrobki zachowujące polski sposób zapisu, w Prodwinie tylko jeden (osoba zmarła w 1909 roku), w Bobrujsku - siedem. Na cmentarzu w Prodwinie na dziewięciu grobach widnieją napisy w języku polskim, ale mają one szyk rosyjski, czyli nazwisko + imię + otczestwo (imię odojcowskie). Pozostałe napisy na wszystkich zbadanych cmentarzach także zachowują ten szyk.

Na nagrobkach z polskimi napisami i szykiem inskrypcje są bardzo skromne: na krzyżu lub pomniku widnieje znak wiary - krzyż, mający po bokach sygle S / S i P (świętej pamięci), niżej imię i nazwisko, pod nim data urodzin i śmierci lub tylko śmierci, czasami też liczba przeżytych lat i data śmierci. Rzadziej pod krzyżem z syglami widnieje napis: Tu spoczywa. Na dole pomnika może znajdować się apostrofa do Boga (Wieczne odpocznienie), zwrot do przechodniów o modlitwę (np. Prosi o Zdrowaś Maryja, Prosi o westchnienie do Boga), formuła wyrażająca uczucia rodziny zmarłego (Pamiętamy, kochamy, bolejemy - dosłowne tłumaczenie z rosyjskiego: Помним, любим, скорбим, powszechnego na pomnikach katolickich i prawosławnych), czasami też nazwa fundatora nagrobka (Drogiemu mężowi, tatusiowi, dziadzusiowi (sic!) od żony, dzieci i wnuków. Pamiętamy, kochamy i bolejemy) [por. Maryniakowa 2001: 242].

${ }^{10}$ Zdążyłam zbadać tylko część cmentarza w Bobrujsku, dane liczbowe nie są więc miarodajne. 
Poniżej przedstawiamy wybrane przykłady inskrypcji polskich z poszczególnych miejscowości:

Izjumowo:

Stanisława Zabiełłowa

Córka

Szymona i Zofii

ur. d. 27 Września 1865 r.

zm. d. 18 Stycznia 1895 r.

D. O. M.

Tu spoczywa

S. P.

Tekla z Pancewiczów

hrabina

Zabiełłowa

ur. 1802 r. zm. 1862 r.

d. 6. października
D. O. M.

Tu spoczywa

S. P.

Antoni hrabia

Zabiełło

ur. 1785 r. zm 1862

[róg płyty utrącony - M. O.] oktobra

Z trzech nagrobków poza kaplicą odczytałyśmy tylko fragmenty: na dwóch - „Tu spoczywają zwłoki Ś. P. Zofii (?) z Radziejowskich ... zm 1867”; „Tu spoczywa...”, „Tu spoczywają zwłoki...”. Na tym cmentarzu jest też nowsza część, gdzie grzebie się zarówno katolików, jak i prawosławnych, oczywiście tych ostatnich jest więcej.

Domanowo

$\mathrm{S}+\mathrm{P}$

PACKIEWICZ

MAPIA IWANOBNA ${ }^{11}$

190306.9 - $198321.10^{12}$

PAMIEC O TOBIE

W NASIH SERCACH

Bzonislow Lipski

1928 17. VII - 199319.08

${ }^{11}$ Litery wytłuszczone oznaczają wszelkie odstępstwa od pisowni polskiej.

12 Zapis daty jest dość charakterystyczny: pomiędzy 19 a 03 w postaci ułamka zapisany jest dzień i miesiąc. 
GUDIŃSKI WIKTOR Sś ANDRZEJA

1.VII. 1918 18.X.1994

Drogiemu mężowi, tatusiowi dzadzusiowi od żony, dzieci i wnuków.

Pamiętamy, kochamy i bolejemy.

Przykład nagrobka z pomieszaniem łacinki i cyrylicy:

$\mathrm{S} \uparrow \mathrm{P}$

Edward Osipowicz

13.IX. 1936

Трагически погиб

$16-\mathrm{X}-1981$

Дорогому, горячо любимому мужу отцу от скорбящей жены и сына

Prodwino

Tu spoczywa Boki Jaś

ur 1876 um. 28.06. 1960

Tu spoczywa Bokaja Katażyna

Ur 1880 um. 1973 lutym

Pamiontka dla kochanych rodziców ot córki Lioni i wnókow

$\mathrm{S} \dagger \mathrm{P}$

Tu spoczywa Tracewski Antoni Edwardawicz

ur. 1876 roku

um. 24. V. 1939

O zdrowaś Maryia

Pamientka ot żeńca Bokaha Józefa j curki Bokaj Janiny

$\mathrm{S} \dagger \mathrm{P}$

Tu spoczywają

ojcec Boki Wincenty Adamawicz

ur. 1873 um. 1939 r.

i brat Boki Ian Wincentawicz

19221943

Proszą zmuwic Zdrowas Maryia

Pamiec ot syna i brata Józefa 1964 20.V.

Przedstawiłyśmy tu tylko ogólne dane. Bardziej szczegółowa analiza napisów nagrobnych będzie przedmiotem innej pracy.

Zadania wytyczone przed wyjazdem zostały w znacznej części zrealizowane. Rozmowy z proboszczem rzymskokatolickiej parafii w Bobrujsku Jurijem 
Bykowem, pobyt na cmentarzach, rozmowy z parafianami pozwoliły zorientować się w obecnej sytuacji Kościoła katolickiego, dystrybucji funkcjonalnej języków praktyk religijnych. Jeśli chodzi o zadania związane z osobą Floriana Czarnyszewicza, sprawa jest trudniejsza. Wiedza o nim jest tam znikoma. Autor Nadberezyńców urodził się w roku 1900 pod Bobrujskiem. Nawet jeśli był chrzczony w kościele pod wezwaniem śś. Piotra i Pawła, jest to nie do sprawdzenia - księgi parafialne nie zachowały się, gdyż kościół spłonął w 1902 roku, a nawet gdyby je uratowano, mogły ulec zniszczeniu przez komunistów. Miejscowości opisane w powieści w niewielkiej części pokrywają się z obecnymi. Na cmentarzach, które odwiedziłyśmy, znalazłyśmy tylko dwa nazwiska pojawiające się w powieści: Tryzna i Sokołowski.

\section{LITERATURA}

Czarnyszewicz F., 2010, Nadberezyńcy powieść w trzech tomach osnuta na tle prawdziwych wydarzeń, Kraków.

Iw a now M., 1991, Pierwszy naród ukarany. Stalinizm wobec polskiej ludności kresowej (19211938), Warszawa.

Karaś H., 2010, Cmentarze na Litwie jako znak wielokulturowego dziedzictwa Wielkiego Księstwa Litewskiego, [w:] Językowe i kulturowe dziedzictwo Wielkiego Księstwa Litewskiego. Ksiegga jubileuszowa na 1000-lecie Litwy, Bydgoszcz, s. 61-75.

Kościół - Kościół w Rosji i na Białorusi w relacjach duszpasterzy (1892-1926), 1999, wybór tekstów i oprac. M. Radwan, Kraków.

Kozłowska-Doda J., 2000, Język polski napisów cmentarnych z Białorusi środkowej (rejon dzierżyński), [w:] Kontakty językowe polszczyzny na pograniczu wschodnim, red. E. Wolnicz-Pawłowska, W. Szulowska, Warszawa, s. 109-122.

Maryniakowa I., 2001, O języku inskrypcji nagrobnych na pótnocnych Kresach, [w:] Studia nad polszczyzna kresowa, t. 10, red. J. Rieger, Warszawa, s. 241-246.

Słownik geograficzny Królestwa Polskiego - Stownik geograficzny Królestwa Polskiego i innych krajów słowiańskich, 1880, t. 1, Warszawa.

Stelmaczonek A., 2002, Język polski napisów cmentarnych parafii dryświackiej koło Brasławia, [w:] Język mniejszości w otoczeniu obcym, red. J. Rieger, Warszawa, s. 87-92.

Werenicz W., 1989, Procesy interferencyjne w imiennictwie osobowym Polaków w byłym ZSRR, cz. 1: Nazwiska, [w:] S. Wa rchoł (red.), Interferencje językowe na różnych obszarach Stowiańszczyzny, Rozprawy Slawistyczne 4, Lublin, s. 297-307.

Werenicz W., 1993, Procesy interferencyjne w imiennictwie osobowym Polaków w byłym ZSRR, cz. 2: Imiona i formy nazywania, [w:] S. Wa rchoł (red.), Gwary mieszane i przejściowe na terenach słowiańskich. Księga referatów Międzynarodowej konferencji naukowej w Lublinie i Zamościu 25-28 kwietnia 1989 roku, Rozprawy Slawistyczne 6, Lublin, s. 355-363.

Werenicz W., 2001, Napisy nagrobkowe z Kojdanowskiego jako świadectwo stosunków etnicznych, społecznych i wyznaniowych na środkowej Białorusi, [w:] Język i kultura białoruska $w$ kontakcie $z$ sqasiadami, red. E. Smułkowa, A. Engelking, Warszawa, s. 169-186. 
Zasztowt L., 1997, Szkolnictwo na ziemiach litewsko-ruskich (od 1795 r.), [w:] I. Grek-Pabi sowa (red.), Historia i współczesność języka polskiego na Kresach wschodnich, Warszawa, s. 202-298.

Аўсейчык I., 2010, Бабруйская крэпасиь: помнік гісторыі і архітэктуры, „Беларускі гістарычны часопіс", № 9, с. 18-30.

Дода Я., 1997, Моўныя асаблівасці надмагільных надпісаў беларуска-літоўскага сумежжа, „Весці Міжнароднай Акадэміі вывучэння нацыянальных меншасцей”, № 2, с. 34-36.

Маліноўскі В., 2008, «... I будуць расчьнены брамы»». Гісторыя касцёлаў Бабруйска, Мінск.

Нен адавец А. М., 1998, Летапіс горада на Бярэзіне (1387-1917), Мінск.

Чаропка В., 2010, Бабруйск: горад-папялушка, „Беларускі гістарычны часопіс”, № 9, c. 3-17.

\section{ANEKS}

Teksty gwarowe zapisane od kobiety urodzonej w 1935 roku w Prodwinie (Rozmowa przy śniadaniu)

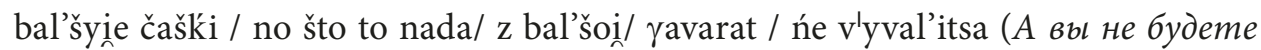
Huчего ecmb?) i ia budu i ina budu / tolka ia / zn'aiec'e što / diiinetu sabl'udain / kašku // možet i vam kaški dac'?// (Какая кашка?) afs'ınaina / davainc'e / u ḿeńa nới bal'ać / no dyk ia eta sama /dainc'e tar'ełoč́ku / i vam ieščlo ńemnoško // u ḿeńla ies'c' ieščlo v́in'o/ dam'ašńe /e /(Эmo nomoм) v'yp’iem / dam'ašńe e / bes

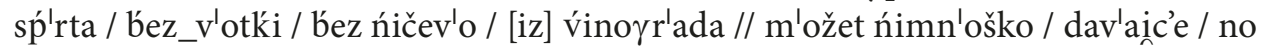

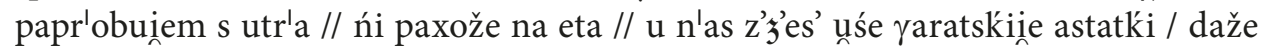
r'uma'k ad'in'akovyx ńetu // ńemnoško papr'obuic'e // xar'ošyịe r'umki / prawda?/ [do kotka] k'ac'a / ty eta [wino] ńe upotrebl'aieš / no / za fstr'eču / (na zdrowie) na zdr'ov́e / da // (dobre) no užle yot stailit // (Это муж делает или выь?) eto ia

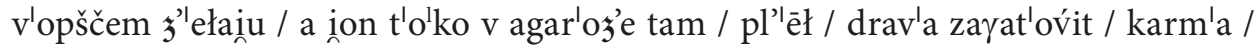

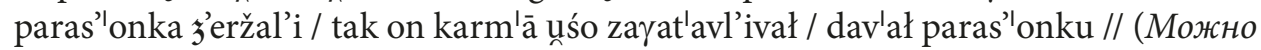
nопросить соль?) i sal'anka vot tak'aira / aya ia [kaszy] ńe sal'iła (У вас есть икона Остробрамской Божьей Матери?) iе̄s'c' / iēs'c' / eto ieščlo m'aḿina / ín vam pakaz'ała / f_sp'al'ńe / a eta n'aša / bełar'uska m'at'er b'oža brasł'aunska // iin'uń pa b́ełar'usku nav́lerno člerv́eń / ia i sam'a ńe zn'ainu // u ḿeńla kal'end'ar v́is'it / dyk ia / bełar'uskii // kak eta t'ep’er žńliveń //[pielgrzymka do sanktuarium

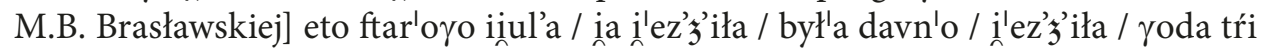
// no c’iṕer ia užle ńe in'ežžu / patam'u što noýi bal'at // [było zawsze] 'ôčeń / 'ôčeń xarašlo / l'ư⿱z'ei met'(?) l'uż'ei //

vot l'il'a maín'a v'yšła za pravosł'avnaya z'a muš // tak et'ot vaproz_był // nu prlavda / ańli raspis'ali s’a / a v́enčlacca był tak'oi vapr'os /on ńi un_kak'oi u__kaśćloł / a inan'a 
ńi un_kak'uiu c'erkof' / i d'ołya vr'em'ia rešlałs’a 'etot vapr'os unu_il'ix i ńi za_št'o ńe paš'oł na ust'upḱi iei // no ia už'e mołčlała // i'esl'iby ôn k_nam pryšloł v_dom i žył u_n'as / my kańe'šńe byž starali s’a / a tak an'a / u_ńeh'o troxk'omnatnaina kvart'ira un_ḿinske i ian'a pašł'a tud'a / a on tože v́leruiuščyi [...] x'oz’it f_pravosłlavnuiu c'erkaf / vot/ i ńik'ak i ńik'ak // iei c’ažeł'o // tem b'ol'eie / što an'a była / xaźliła f kaśćloł / an'a fsir 'u d'ušu addav'ała / an'a i rr'ała na arg'anax / pr'osto / vyž_v́liz̉el'i / my patxaz'lil'i k_ń'ei i ieielo pŕiv́letstvovali / patam'u što an'a ôč́eń xarašlo ṕeła

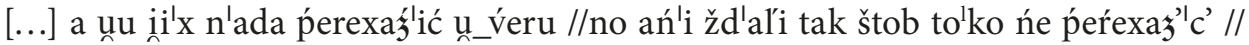
an'a yavaŕlit už'e ł'adna paid'u / uñ̌le pav́enčlaiemsa / to'ka št'oby ia ńe c’er'ała svoil'u v́leru // vot tak ix blac'uška i pav́enčlał ńe c'erlafšy / ńe c’erlafšy // an'a f_kaśćloł a on $\mathrm{f} \_c^{\prime}$ erkof // beŕliće kałb'askí / kaša ńemnoško / (Очень вкусные помидоры)

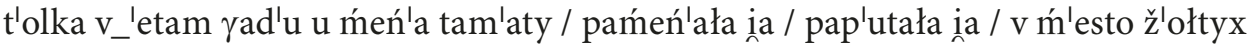

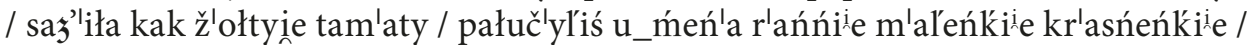
vot taki'i i i fś'e / ń'eskolko t'olka k'al'evek ast'ałos’a ž'ołtyx / dyk ast'av́iła na śeḿian'a / a tak unśle r'ańńi e kr'as'ńeńki e m'al'eńkiie byli / rano k'ončyl'is' // može s'ol'ki nado było / i sal'lanka m'al'eńkaina 'eta / p'usta v́eć //(Ваша кошка ещё маленькая?)

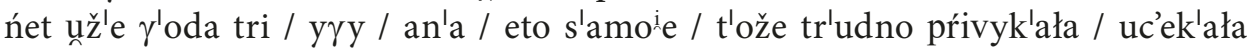
an'a ad_n'as // m'al'eńkaia m'aleńkaia był'a //dyk / a pat'om uñ̌̌́e za tr'ećim r'azom

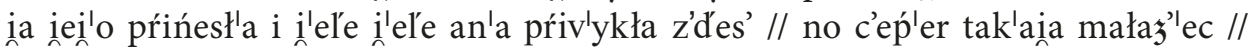

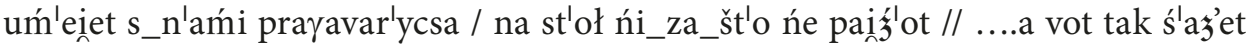

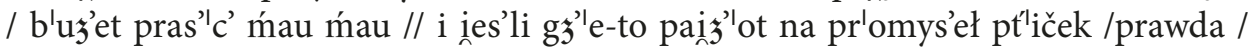
lav́lic' pt'iček i myšlei pa_p'ol'u // vot id'ot už'e / prayulainetsa tam / id'ot i ḿau / príiv'etstvuiet už'e // an'a ot tože pŕińes'ot pt'ičku // [...] pat'om /ot ia ńe zn'ainu / kak u_v'as nazyv'ainetsa / te s'amyie i i'aščerycy / ílaščeryca d'l'ińeńka / t'ože prín'os'ic'

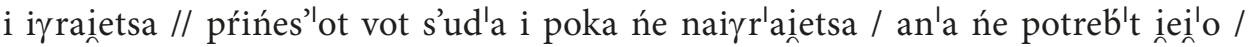
i dai' ot ł'apkoi ras / an'a šev́el'itsa / an'a aṕlac' ł'apkai / int'er'esno rul'ain // kr'ysy /no no // pryńes'ot i pak'ažet / što on rab'otu z's'ełał / da // beŕlic'e kałb'asku i'ešc'e

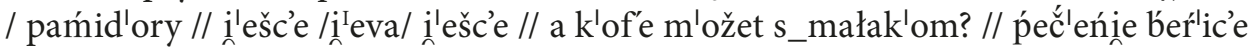
ṕĕ́leńíe //(Это польская скатерть у вас?) eta u mńe tak / eto ... príivaz'il'i / da / dyk pap'ała d'v́e tak'liie /adn'a ḿ'enše tam na kaŕid'ore // orn'aḿent // maćlif // (А как вас крестили?) do vainn'y kas'c'oł był // iešč́lo moi s’'eduška pak'oinnik / vot on z'z’es' paxar'ońen / fel'iks /tak ońi /eto s'amoie // eto rassk'azyvała m’āma

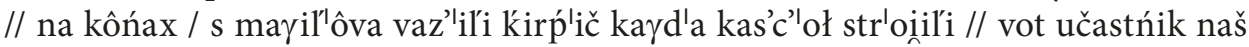
ई'eduška był // (Как вы принмали первую комунию?) vot c'eṕ'er ร’'etki pŕińim'ainut

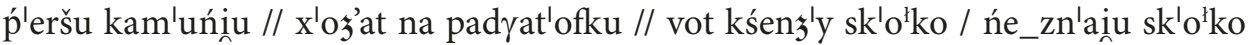

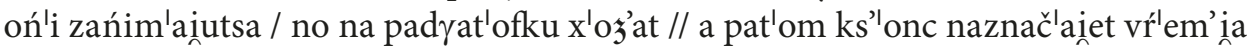
/ v_l'etńeine kań'ešno vŕlem'ia / na kańlkułax / i ṕ'ervoine príčlast'ie pŕińimlainut kam'uńa // a u_n'as / u_n'as // iaž yavar'u što my ńe pŕińim'al'i //ot kagd'a u_ḿeńla l'il'a m'al'eńkaia był'a / my i'ez's’il'i u_kr'asnoie / tut u_bełar'uśi // tam kas'c'ol rab'otał // vot / eta / eta/ kak vam skaz'ac' kr'asnoie za_ḿlinsk ili ṕ'ered_ḿn'nskam

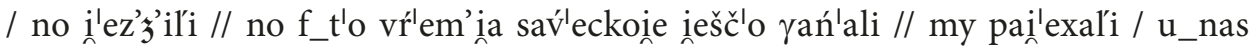
maš'yna był'a/ my pain'exal'i // i l'il'a main'a stain'ała u_'očereži dô sp'ôvej’i i ina // 
i pat'om kamuńlisty pryšll'i i razayn'al'i / nam pŕiššl'i skaz'ali / što pŕiššl'i kamuńlisty // as'ob́enno šk'olńikof // pat'om saapščlali u_šk'ołu / pat'om vot // no vot / dak ia dak sxaz'liła tam k_sp'ov́ez’i a l'il'a ńe sxaż'iła vot // a ia / napŕín'er // eto było va vŕlem' ia vain'y // ḿeń'a kres'c'lli / ia p'omńu eta vot / no ia ńe pŕińim'ała príčlast'ia / ńi k_sp'ov́ej’i patam'u što ń'e_było vot // a kagd'a kres'c'li / ia p'omńu / eta była va_vr'em' ia vainn'y // mńe nav́lerna b'yła s’em / što ia p'omńu i ḿ'eńšaina śestr'a

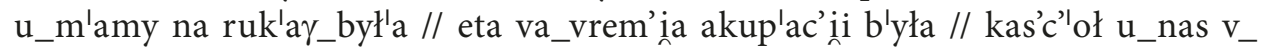
babruiske rab'otał f_ṕ'ervoie vr'em'ia vainn'y i nav́lerno ńeḿez_był ks'onc // tak što u_ḿeńla ṕ'ervaia kam'uńia był'a kagd'a my pav́enčlalis' / ia tagd'a da_sp'ov́ez̧i sxaz'liła i eta s'amaine / vot tak'oine b'yła // no ia rada i tam'u był'a // ia praśliła muža

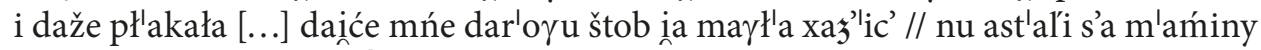
s'l'ed'y // m'ama naša oč́eń vériła // (А мама учила вас молиться?) uč'ỳła / uč'ȳła / f́́o vr'em'ia my mal'ili śa (на каком языке?) na p'ôl'skam / na p'ôl'skam // i vot ia to'ko c'eṕ'er zap'omńiła ia n'ačała tav'a učlyc' čyt'ac'/ pa_polski xac'eła / i s_'et'ix mal'itf / ia / mal'itv́enńiki b'yli u_nas / ia br'ała mal'itv́enńik // 'oiče naš ina to zn'ała / a pat'om štoby znac' b'ukvy / ia pa_ mal'itv́enńiku učyła // i tak ia v v'yučyła čyt'ac'

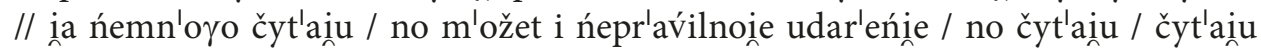
t'olko pa_mal'itv́enńiku // a ruk'oi što ṕlisano / ia né fś'o zn'ainu //no// no ii c’eṕ'er u_ḿeńla / vot ia i xac'eła i spras'lic' u_vas / ta mal'itva kat'oraia mama naučlyła // no słav'a ńep'ołnyie ńeilasnyie i ńepr'av́ilnyie // vot napryḿ'er:

kład'ymsa spac' / ńe m'ožem ńic zł'ega stać / ań'oł božy do pomocy doskan'ały /vot 'eto sł'ovo / a eto d'avńešńaia mal'itv́a i ia iei'o p'omńu / no sł'ova doskon'ały ...// kład'ymsa spac' / ńe m'ožem ńic zł'ega stać / ań'oł božy do pomocy doskon'ały/ naị́nil'eiñ šy bar'anek / kt'ury l'ežy pan in'ezus u_gr'obe / dai nam otp'očnońć pšy t'obe //

vot słav'a / vot 'eti vot mńe ńėíasny //

vot u_ḿeńla p'aṕina b́'ibl'iia ieščlo ast'ałas' / vam pakažlu // u m'amy b'yli st'aryje, st'aryje kślonžečki / dak my raz'̧̌̉ el'il'i ḿeždu sab'oj i mńe pap'ała eta blibl'iina / a tr'om s'ostram t'ože pa mal'itv́eńniku // i vy pasmatŕliće eta prosta pere... eta nu drư'aia abł'oška // i vot ia z'im'oi / ciṕ'er ia m'ała čyt'ain / a z'im'oi / kak načyn'ainetsa dyk ia čyt'ainu // [bukvy] m'al'eńkiine / no pok'a ia pok'a v́ližu, no pańílatnaina 'eta pańílatnaina tak'aina b'libl'iia pańiatnaia // m'amína fślo // no p'apa paýlip va vŕlem'ia vainn'y/ a m'ama čyt'ała i mal'iłas' / ružlańec u ieini'o s_ruk ńe

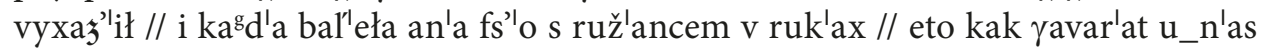
ńespoz̉ev'anaia s'ḿ'erc' pr'avda // no kań'ešńe [...] u n'ašei m’amy // an'a mal'iłas’a / a tŕin'acac' rad'ou l'ežlała / mučyłaśa / i nam b'yło c’ažeł'o / rab'otali / mał'yie źlec'i / šk'oła / i an'a l'ežlała / no u_n'as tag_b'yło / što vot / č́'etv́ero naz_z’ec'ei / d'oč́ek i my tak apred'el'il'i / što adn'oi t'ažeł'o fśo vr'em' ia s’erž'ac' tak an'a pab'uz’et

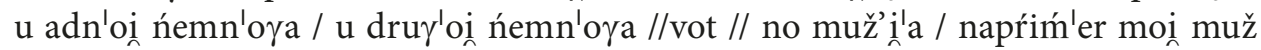
/ dak / był tak'oi ńixar'ošyi / no / ia k'ak-ta ńi skaz'aunšy iem'u zabr'ała m'amu /

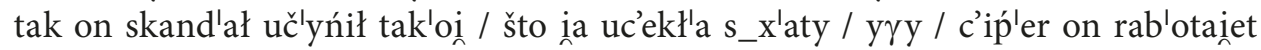
/ uže votku ńe vyṕiv'ainet / a tag_doma ies'li vot tak v́in'a v'yp'in iet i fślo a tagd'a 
šaf'orom rab'otał / m'ožet i ž́enščyny b'yli u_iev'o / kto ier'o zn'ainet // no a nam b'yło kań'ešno žlałko m'amu / my že vḿles'c'e s_ń'ei u_z’er' 'evńe // an'a l'ub'iła

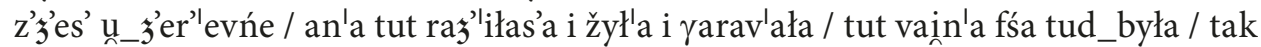

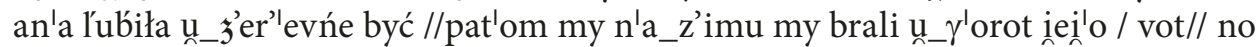
an'a star'ałas’a što-to pam'oč // s'ižeła an'a ńe xaz' liła // no ieščco i l'il'a main'a / an'a

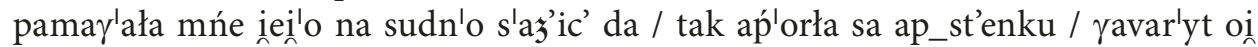
m'ama ńeuž'eli ia budu s_taboi m'učycsa tak // to že s'ama i mal'iła s'a i vot n'ada b'yła bal'ec' st'olka / no tak sužžen 'o // t'ože mama n'aša / a kto pain'av́its'a ili vrač ili ḿeds'estr'yčka / an'a tak s_uł'ybočkoi fstrečlała vs'egd'a // 'eto u_moin'ei s'estrly vot etoi što była sa_mnoi vḿ'es'c'e f_kas'c'ol'e / u i ieilo že syn paḿlor // my d'umali što on paḿ'or / a iev'o ub́lili // s'orok ṕat' s'orok šes'c' radou // takoi xar'ošyi syn kras'av́ec / dup /no i t'eṕ'er apredd'el'il'i / už'e sl'etstv́iie iž̃ 'ot / što iev'o kt'o-to ub́lił // d'oma/ d'oma // i ńikav'o ńe b'yło / ńi žen'y / ńi s’ec'ei //m'ožed_byc' d'aže // no

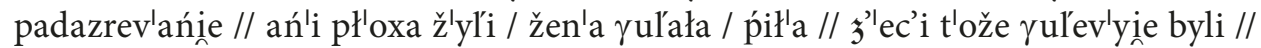

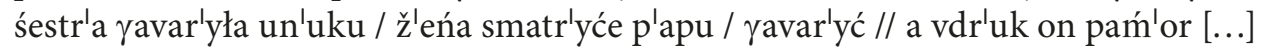
syn tak šesn'accac' l'et // no tak padazr'eńie na svainlix //

str'ašna / str'ašna // no i pryšł'os'a tak / a paḿ'or on kak_r'as pry_s'estr'e // v_ vaskŕes'eńie s_kaśćloła an'a v'yšła i pailexała k_ńem'u // ńikav'o d'oma ń'e_było // vad'y pad'at' ńe_było [...] i pry_ń'ei on 'umer [...] s'l'etstvíie id'ot // iei'o dapr'ašyvali / byli p'i i'anyie // ł'ožnyie pakaz'ac'eli dav'ała dyk na 'etot st'uł saýlil'i ieilo // vot// no što ia xačlu skazac' / my na p'oxoronax t'ože sabr'al'i s'a / s_kaśćloła ž'enščyny i my s_val'us'ei pryšl'i /vot/ dak vot v asnavn'om mal'il'is'a a pat'om ṕel'i žał'obnyie ṕes'ńi // dak 'etot un'uk zapreščał nam // pryšloł / da s'er'în'ôzno / prekrat'ît'e vam

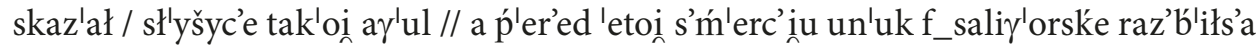
na_mašlyńe // eta ḿ'es’ac s_člem-to praš'oł / b'ol'še ḿ'es'aca / vot tak'oi a a 'ul' //

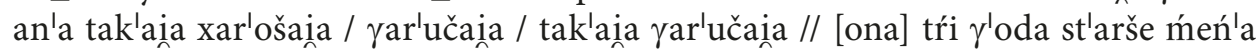
t'olko / no a vot tak'oie // i fs'il'u žyz'ń yarav'ała f́so / a pat'om kagd'a razrešyl'i učlastki zańim'ac' / an'a vz’ał'a 'etot učlastok / razrab'otała // i xar'ošyi kak_r'as

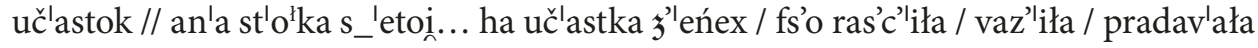
i fs'o $\mathfrak{z}^{\prime}$ 'ec'am / i fs'o 'etamu s'ynu // sam'a sł'ab aia / u iein'o batar'eika fst'avl'ena s'erca

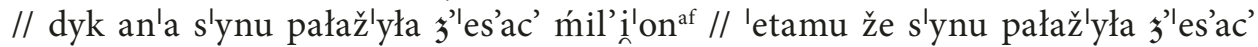

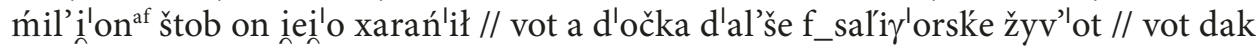
an'a / on pabl'iže / tak vot fśo an'a addav'ała to d'očḱe to s'ynu // a ńev́lestka vot tak'aina / no iein'o ańli i ńe xac'el'i / an'a był'a tak'aina / kagd'a žeń'iłs'a adyav'aryvali

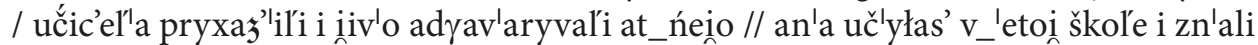

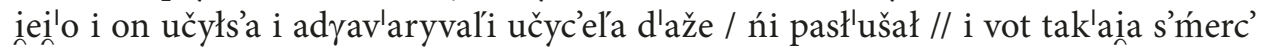
/ było tak'oie $\gamma^{\prime}$ ore / ia sam'a vot kak usp'omńu / kak usp'omńu 'etot s'aša l'ežlał /

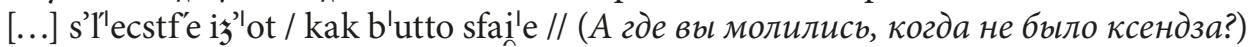
da / d'oḿig_był mal'itv́ennyi / kuṕlili / kat'ol'iḱi sabr'al'i s’a i kuṕlili d'ômikik i xas'lilí tud'a mal'il'is'a // mal'il'is'a // no skołko eto yad'ou b'yło ia tak ńe p'omńu /no ia zn'ain što ia xaźliła tud'a $\gamma^{\prime}$ 'od // xac'eła naunučycsa mal'icsa patamu što ia znała ôtče naš zdr'ovas' mar'yia vot véžeń v boga unonoinca / astal'n'oie d'umain no xoz’by 
i čyt'ac' naučlyłas'a / no dyk už'e t'ože i rab'otała i 歺'ec'i i xac'ełos'a // k'aždoie vaskr'es'eńie i'ez'żiła v_etot d'oḿik vḿ'es'c'e vḿles'c'e s_etoi s'estr'oi i mal'il'is'a /

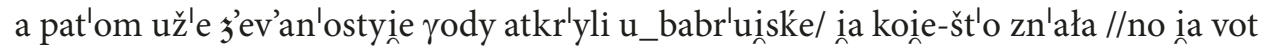
ńe zn'ain // eta uže on [domik] d'ołžen był kas'c'ołu prynadležl'yc' // tak c'i on ańli prad'al'i / no ia eta ńe zn'ainu / no eto už'e pai żł'ot koń'ešńe / xot' i ńe prad'ali / eto dl'a kaśćloła už'e buż'et i pat'om nav́lerno dv́e ž'enščyny uḿir'al'i i svain'e kvart'iry zav́eščal'i kaść'ołu // (Был ли в этом домике кто-нибудь, кто вёл молитвыเ?) da, da był'a ž'enščyna / no an'a był'a ńexar'ošaina / no už'e uḿerł'a eta ž'enščyna // an'a

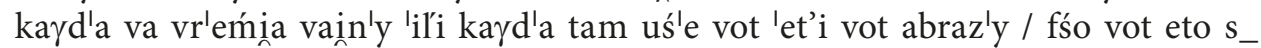
kaśćloła / an'a v́ližimo s_kaśćloła pazabir'ała i xarańliła u_śeble i ńi addav'ała //

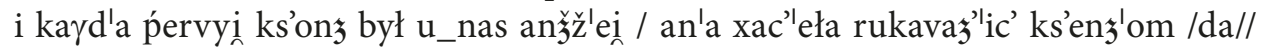

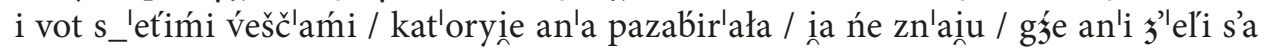
vot 'et'i v́leščy // c'i an'a add'ała // no an'a uḿerł'a sam'a // a star'ałas'a być st'aršei

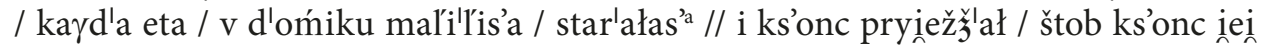
pațčyńlałs'a // tak'aina ž'enščyna był'a ńexar'ošaina // ńexar'ošaia był'a ž'enščyna // no an'a uḿerł'a vot // no 'etí / ia už'e ńe zn'ain ģ̧e // (Когда вы встречались?)

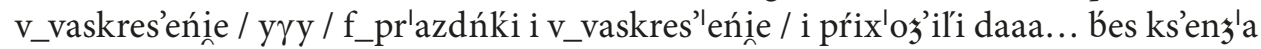
(Как вы молились?) no ia znaí / što vot an'a no mšu pravaz'liła / mšu pravaz'liła

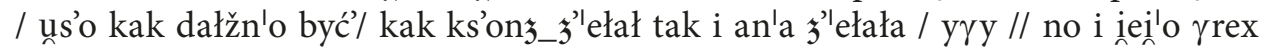
vot eto vo / što an'a ńe addav'ała // vot ks’onc iei ńe pațčyń'ałs’a / zn'ačyt an'a ńe addav'ała et'i v́leščy // a pat'om §’e ia ńe zn'ainu / iuzefa / no an'a uńerł'a / no iešččo

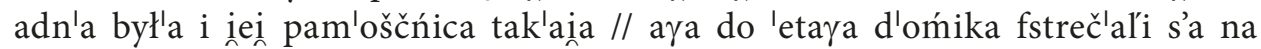
kł'adbiščax // u_n'as na kł'adbiščax paxar'ońeny dva ks'enz'a /i ad'in ks'onc paxar'ońen u kas'c'ole / u kas'c'ol'e / tam v́id'ac' m'esto tak'oie što był'a padńlata pl'itka // tak fstrečlal'i s’a u maýliły ks'enz'a i tam mal'il'is'a /vot// i t'amže b'abuška naša / m'aḿina b'abuška $\mathrm{v} \gamma^{\prime}$ 'orože paxar'ońena /an'a p'os'le vainn'y sr'azu uńerł'a a $\mathfrak{z}^{\prime}$ eduška m'aḿin p'apa tut paxar'ońen // my c'eṕ'er x'ožim uns'egd'a na kł'adbišče //(Как вы хоронили умерших, когда не было ксендза?) mal'il'is'/ pŕi үrobe mal'il'is'

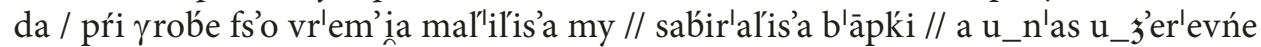
dak na fs'un'očnuiu / kayd'a p'asxa dak doma sabir'al'is’a / t'ože u adn'oi b'apki sabir'al'is’a / fs’un'očnuiin / mal'il'is’a // a my b'yl'i m'al'eńkiiie dak my [...] sł'ožyms’a i sp'al'i / sp'ali // pat'om už'e r'ano 'utrom na_ras's'vec'e užle podym'al'is'a / užle v́es'ołyie / šli pat'om // (Кто святил продукты на Пасху?) а b'yła sol' s'v́enc'ona / s'aḿi s'v́ac'il'i s'ol'inu / a ra razvaz'il'i sol' i 'eta vad'ička s'v́enc'ona b'yła // fs'o

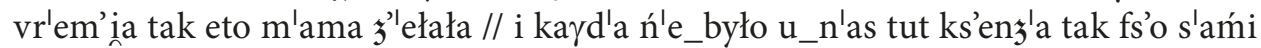

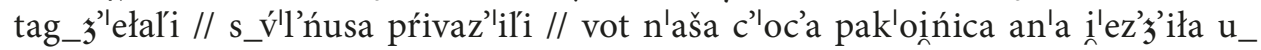

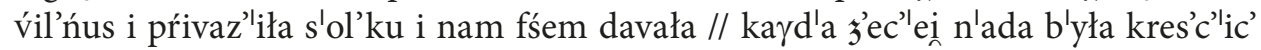
/ dak an'a b'ystreńko saapščlała / štob_eta b'ystro pakŕes'c'ili // fs'o tak z’'ełali fs'o kak môžna była eta // da sama głaźna što zaxav'al'i v́leru / v́leru zaxav'alí // ( $\mathrm{Ha}$ каком языке вы молились около покойника?) pa_p'olski / r'ańše fśo pa_pol'ski i ṕes'ńi /kakiiie marl'i / takiiie pa_pol'skí // a c'eṕer' už'e na bełar'uskam // u_nas mša pa_bełar'usku // už'e skaz'ali tak / no što kto žyv́lot v_b́ełarus'i / kań'ešńe eto 


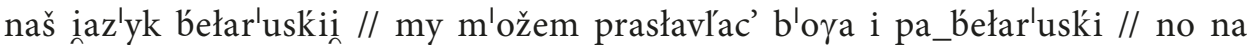

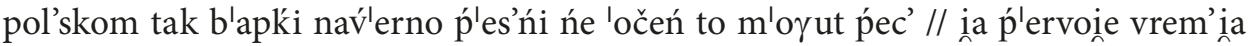
xaz̧'iła f́́o na p'ol'skuin mšu / vot // a pat'om nam zručńeine v_żer'evńu v eto vr'em'ia pryiežžlaiem / a tam 'očeń r'ano my príii'ej’em // no tak na bełar'uskuiu [mszu] // ranše ia t'ože fs'o naiz'us'c' zn'ała // ńe pa ks'onške // kak ks'onc yavar'ył atv́ečlała pa_p'ol'ski i fś'o pryučyłas'a k_pol'skomu iazyk'u // no a pat'om už'e pa_ bałar'uskii i st'ała p'utac' tud'a s'ud'a / tud'a s'ud'a // (Какой был ваш первый язык, на котором вы общались с мамой?) eto i był bełar'uskiii vḿes'c'e s_ruskim / vot // a m'aḿina s'estr'a u g'orože ž'yła / vot eta [...] u ńein'o d'očka był'a 'ała // an'a razłav'aryvała na p'ol'skom iazyk'e s'estr'a maḿlina // a my už'e m'ama rab'otała / kałx'oz_był / zab'ota / pa p'ol'sḱi už'e as'oba ń'e_było kagd'a 'učyc' v_ieín'o rab'ota / rab'ota // dak my // mal'itvy byli u_n'as na p'ol'skom iazyk'e / apščal'is'a na bełar'uskom i škoła była [biełaruskaina] četyŕe a patom [tri] / s’em ia zak'ončyła / s’em [kłasow] // b'abuška an'a uńerł'a // an'a ravar'yła pa p'ol'sḱi kańešńe / no ia

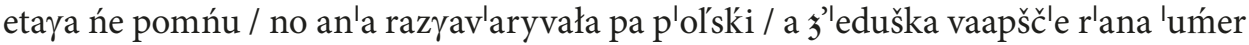
/ vot / a b'abuška razyav'aryvała s_'etai dočkai svain'ei [...] //(Какая была бабушкина фамилия?) b'okiiie / b'okiie (Бокие? Это не польская и не беларусская фамилия) iaž yavar'u / nav́lerna napole'ôn tut ast'av́ił svaílix franc'uzof // no a n'aša dam'ašńaia v́išń'efskaia faḿlil'ia / p'apa v́išń'efskiii był [...] v́išń'oư⿱ka [...] ńet ńet u_n'as st'as'euka ies'c' vot dal'še / vot 'etot aft'obus / dak i ravar'yli / što ot_imeńi st'as'a 'eta ร’eŕlevńa / no tam adńli pravasł'avnyie // u_nas ks'onc r'oman był i ôn arx́livy smatŕ'eł i fs'o i vroz’e_by kak'liie-to vreḿen'a byli štô zastavl'al'i ic'c'li f_pravasł'av' ie 'iz-za z'eml'i / 'iz-za z’eml'i // vot eta vot st'as'eukka / no ańli fs'e pravasł'avnyie [...] ańli byli kat'ol'iki // bełar'us'a pač́t'i fs'a był'a katal'ičeskaia // a vot 'et'i vréénen'a lizza z'eml'i i šl'i f_pravasł'av' ie //(А моэжет быть вы происходите из иляхты ?) no nav́erno tak // no p'apa naš / ian___ravaryła / on va_vŕem'ia vainn'y paýlip / a my b'yli m’al'eńkiiie // a m’ožet što i yavar'ył / no ńe p'omńu // a pat'om inev'o zabr'ali

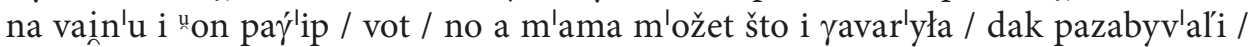
ńi abraščal'i as'obaya vńim'ańiina // (Когда умерла ваша бабушка?) b'abuška sr'azu p'os'le vain'y // a kak'oi eta yod_był / ia ńe zn'ainu // (До войнь многие тюди разговаривали в деревне по-польски?) nav́erna // m'ožet main'a s'estr'a zn'ainet 'eta // sx'oz’im vot k_s'estŕle i na kł'adb́išče sx'oz’im m'ožet an'a / m'ožet ieiílo muš_št'oto p'omńit vot // muš u_ńeilo t'ože kat'olik / no ńe v́lenčany // v'os'emร̇es’at yadoun / už'e s'c'es'ńlainuts'a v́enčlacca [...] a to s'c'es'ńlaiets'a // no an'a x'ożit u_kas'c'oł

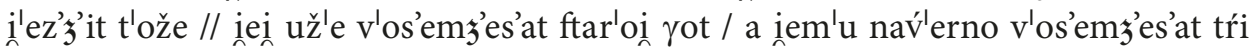
//no ańli tak ieščle ńičev'o // no on ńe i'ez'z’it u_kas'c'oł // on tože s’erd'ečńik on

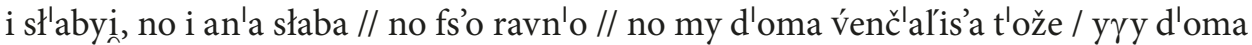

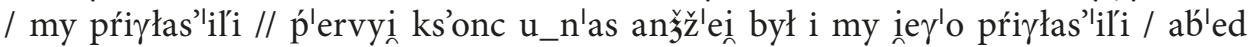

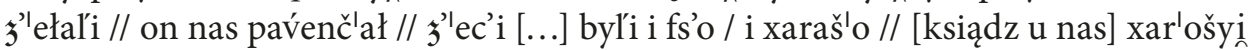
/ u_n'az_był ṕ'ervyi anžžlei / a pat'om ń'ekatoroie vrem’ia zaḿeńlal'i iaš ńi p'omńu // a pat'om ks'onc r'oman był / a pat'om ks'onj_ǵ'eníix i pos'le ǵ'enŕixa i'urii // no

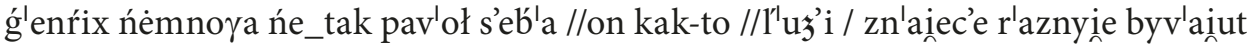


/ r'aznoie fs'o yavar'at // a on adńlix l'uż'ei pasł'ušał / kat'oryie ńepr'av́il'no iem'u d'iktav'ali i ḿeždu n'aḿi był skand'ał d'aže m'ožna skaz'ac' // kto jišlli za_kas'c'oł

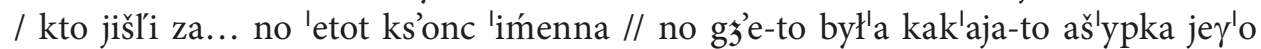
g'enŕixa // [ksiądz Roman] on v_maýill'ov́e užle / na fs'e sažal'el'i kśenz'a r'omana // fs'e žal'eli / on xar'ošyi tak'oj s_patx'odam był / d'obryi / d'obryi był / d'obryi //

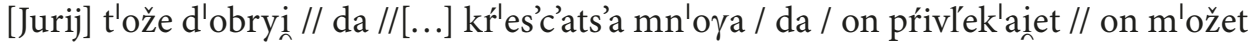
padaiç'i k_maład'ym // i venčclańie ies'c' člasta 'eta / no da // oi ńe_d'ai box / ńe d'ai box nark'otiki // no vot u_n'as napŕiḿler ǵeńin syn žyv́lot az̧'in / tak pałuč'yłos’a / što ańli b'yl'i u_ḿlinsku // an'a rab'otała u_kaŕit'as'e / zabr'ała ièv'o s_sab'oi // on učlyłs'a / b'ožestv́ennoie / 'etava učlylišče b'yła // zak'ončył tam u_ḿ'insku // pat'om $\xi^{\prime}$ 'evočka był'a saǵit'irovała iev'o pastuṕlic' za'očno učlycsa v_instyt'ut [...] vot no ii "on / pr'awda /za'očno učyłłsa // i tak pałučlyłos’a što on u_ḿlinsku i rab'otał // no

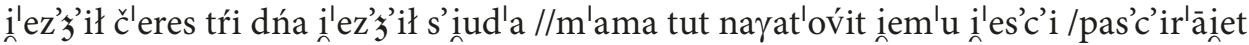
fs'o / on aṕlac' pain'exał // no kal'es'ił tud'a s'ud'a // no eta z''evočka ustr'oiiła z'z’es' iev'o na_zav'ot rab'otac' // no ustr'oiiłs'a on z'z’es' // tut l'il'ia z'a_muž v'yšła / u_ ḿlinsk paín'exała / i tak naabar'ot akaz'ałos' to an'a był'a tut / on tut / i kvarc'ira adnak'omnatnaia vot // my prlavda iešč́lo do żev́an'osty $\gamma_{-} \gamma_{\text {ad' }}$ 'of kuṕlil'i 'etu kvarc'iru l'il'i // no i on z'žes' on aźlin žyv́lot // był mal'eńkiii vot ja xaz' 'iła u_kas'c’oł // l'il'ia xaz'liła i iev'o / i on xaz'lił i słužlył // ḿińistranc'ikam był // on sam ńevys'okovo r'osta był / m'al'eńkii / tak ł'apočki sł'ožyt / tak kras'ivo b'yło / tak

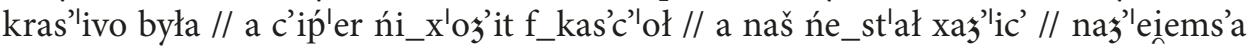

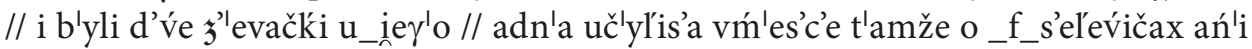
žyv'ut r'adam // no padv́ern'ułasa ftar'aia // on in i'ez'z’ił v_ysp'ańin / fs'o $\mathfrak{z}^{\prime}$ ectvo iev'o prašł'o v_ysp'ańii // t'ože s_kas'c'oła vot tak // u_n'as isp'ancy b'yli i zaṕlisyvalí ร’ec'ei // pr'awda iem'u s’eḿli l’et ńe_było ieščco // no ii ṕlervyi ras pap'ał / i adn'a s'em'ia br'ała i br'ała iev'o v_ysp'ańiu vot // no ii n'ada 'etim isp'ancam ṕeredav'ali iem'u 多'eńǵi /i'anu / ṕeredav'al'i tam už'e // no ii 'eta $\mathfrak{s}^{\prime}$ 'evačka ṕered'ała //

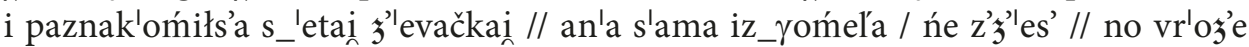
učlylis'a u_ḿlinské / vot // dak ieščlo vḿ'es'c'e b'yli tam // to $\gamma^{\prime}$ oḿel' - babr'uisk iezd'a // to ńe pałučlainets'a to tak / no on star'ałsa k_ńei // vr'oz’e an'a panr'av́iłas'

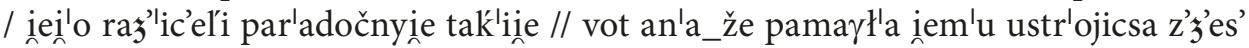
na rab'otu // no ii c’eṕ'er i ńi toi ńi toi nav́lerno ńė_m'a // no uže dvaccac' ṕlatyi yot / už'e m'ožna b'yłoby i žeńicsa // 


\title{
BABRUYSK DISTRICT - HOMELAND TO FLORIAN CZARNYSZEWICZ YESTERDAY AND TODAY (REPORT OF FIELD RESEARCH)
}

\section{SUMMARY}

Field research in Babruysk and vincinity taken up recently is part of research of the religious language of Catholics in former North-Eastern Polish Borderland and writings of Florian Czarnyszewicz, who comes from Babruysk Disctrict, the author of several novels, the most famous of which is called Nadberezhyntsy.

The article presents short history of Babruysk with special attention drawn to cultural - educational problems and the dynamics of population development in this town. It shows functioning of the Catholic Church in Babruysk District in $20^{\text {th }}$ and $21^{\text {st }}$ centuries. It also discusses the language situation in the researched area which is as follows: the primary language in the town is Russian with elements of Belorussian. This language demonstrates great idiolectal diversity. People who live in the country and have never left it use a Belorussian dialect (which confirms the principle that living in the country favours preserving the dialect). The Polish language is present only during the liturgy and prayers of the eldest generation. During Masses said in Polish the Polish language is used for Eucharistic Liturgy but during the Liturgy of the Word Polish is present only for the reading. The sermon is preached in Belorussian. Belorussian is also used for pastoral announcements. Numerous participants of the Mass can be the proof of attachment to the Polish language as the language of liturgy.

During the research trip we visited four cemetaries where we photographed 87 tombs. As for these tombs, we were certain that they belonged to Poles (as surnames, names or father's names indicated). 33 inscriptions out of this number were engraved in Latin alphabet. We could observe mixing Latin types with Cyrillic ones.

The appendix given at the end of the article contains texts of an informant from Prodwin written phonetically.

\author{
БОБРУЙЩИНА - РОДИНА ПИСАТЕЛЯ ФЛОРИАНА \\ ЧАРНЫШЕВИЧА В ПРОШЛОМ И НАСТОЯЩЕМ \\ (ОТЧЕТ ПО ИТОГАМ ПОЛЕВЫХ ИССЛЕДОВАНИЙ)
}

PEЗЮME

Предпринятые в 2010 году полевые исследования в Бобруйске и его окрестностях являются частью исследований языка населения католического вероисповедания на территории бывшего Великого княжества Литовского. В частности исследования проводятся также в связи с творчеством малоизвестного писателя Флориана Чарнышевича, родившегося на бобруйской 
земле. Флориан Чарнышевич - автор нескольких романов, среди которых наиболее известным является «Надберезинцы».

В статье представлен очерк истории Бобруйска с учётом культурно-просветительских аспектов и динамики развития численности населения в городе. Авторами показана деятельность католической церкви на Бобруйщине в XIX-XX веках.

Языковая ситуация на исследуемой территории представляется следующим образом. В городе преобладает русский язык с элементами белорусского. Этот язык сильно дифференцирован в зависимости от личности говорящего. Люди, которые родились в деревне и провели в ней всю свою жизнь, пользуются белорусским говором (что подтверждает наблюдение о лучшем сохранении говора в деревенской среде).

Польский язык присутствует исключительно в литургии и молитвах старшего поколения. На польских мессах по-польски ведётся евхаристическая литургия и литургия слова. Проповедь и объявления священник читает побелорусски. Большое количество присутствующих на польской службе свидетельствует о привязанности католиков к польскому как языку литургии.

Ценным социолингвистическим материалом являются надгробные надписи. На 4 кладбищах мы обнаружили 33 эпитафии, высеченные латинским шрифтом. На деревенских кладбищах наблюдается смешение латинского шрифта и кириллицы.

В приложении приводится диалектный текст, записанный у информантки из деревни Продвино.

Słowa kluczowe: Białoruś, Bobrujsk, historia, sytuacja socjolingwistyczna, Kościół katolicki.

Key words: Belarus, Babruysk, history, sociolinguistic situation, Catholic Church.

Ключевые слова: Беларусь, Бобруйск, история, социолингвистическая ситуация, католическая церковь. 